\title{
Quantitative Autoradiography of Major Neurotransmitter Receptors in the Monkey Striate and Extrastriate Cortex
}

\author{
Pasko Rakic,' Patricia S. Goldman-Rakic, ${ }^{1}$ and Dorothy Gallager ${ }^{1,2}$ \\ 'Section of Neuroanatomy and 'Department of Psychiatry, Yale University School of Medicine, New Haven, Connecticut \\ 06510
}

In vitro autoradiography was used to determine the binding properties and distribution of 9 major neurotransmitter receptors and their subtypes in the striate (area 17 of Brodmann) and extrastriate (areas 18 and 19) cortex of 1 infant and 3 adult rhesus monkeys. Differences in total labeling and nonspecific labeling, as well as $K_{d}$ and $B_{\max }$ values, were determined for all cortical layers and sublayers in both cytoarchitectonic areas by Scatchard analysis of autoradiograms. Area 17 differed from area 18 in the laminar pattern and density of virtually every ligand examined, i.e., ${ }^{3} \mathrm{H}$-clonidine, ${ }^{3} \mathrm{H}$-prazosin, ${ }^{125}$-iodopindolol, ${ }^{3} \mathrm{H}$-quinuclidinyl benzilate, ${ }^{3} \mathrm{H}-5$-hydroxytryptamine, ${ }^{3} \mathrm{H}$-ketanserin, ${ }^{3} \mathrm{H}$-muscimol, ${ }^{3} \mathrm{H}$ flunitrazepam, and ${ }^{3} \mathrm{H}$-spiperone. $K_{d}$ and $B_{\max }$ values for each ligand were remarkably consistent across the 3 adult monkeys analyzed quantitatively. Particularly dramatic contrasts were observed with clonidine, 5-hydroxytryptamine, and ketanserin, which have high affinity for $\alpha_{2}$-adrenergic, $5-\mathrm{HT}_{1}-$, and $5-\mathrm{HT}_{2}$-receptors, respectively. The differences in distribution of these ligands, especially clonidine and 5-hydroxytryptamine, correlated well with specific laminae and hence exhibited distinctly different patterns in areas 17 and 18. Other ligands, such as flunitrazepam and quinuclidinyl benzilate that bind to GABAergic and cholinergic receptors, were visually less discriminating both among layers and between regions. However, layer for layer, the $B_{\max }$ values for quinuclidinyl benzilate were higher in area 17 than 18, indicating that subtle differences between areas may be revealed only by quantitative measures. Some ligands were particularly dense in layer I (iodopindolol in areas 17 and 18; 5-hydroxytryptamine in area 18), and others subdivided cortical layers that are otherwise cytoarchitectonically uniform (e.g., flunitrazepam and clonidine in layer VI of area 17), indicating that areal differences in ligand binding are not a simple read-out of cell-packing density but most likely reflect a genuine difference related to the neurotransmitters of intrinsic and extrinsic afferents in each area. The presence of binding sites in every layer of both areas for all ligands examined indicates that their distribution across laminae is quantitative and not all-or-none. No layer contained less than $50 \%$ of binding sites present in any other layer. These find-

\footnotetext{
Received Aug. 18, 1987; revised Nov. 19, 1987; accepted Jan. 11, 1988

This research was supported in part by United States Public Health Service Grants NS22807 and EY02593. We are grateful to J. Loubier and C. Dean for technical assistance.

Correspondence should be addressed to Dr. Pasko Rakic, Section of Neuroanatomy, Yale University School of Medicine, 333 Cedar Street, New Haven, CT 86510 .

Copyright (C) 1988 Society for Neuroscience $0270-6474 / 88 / 103670-21 \$ 02.00 / 0$
}

ings reveal that visual cortical areas differ in density and lamination of neurotransmitter receptors and presumably in their sensitivity to circulating levels of endogenous neurotransmitters and pharmacologically active compounds.

Modern neuroanatomical and electron microscopic techniques have provided unparalleled information about the intrinsic circuitry and input-output relationships of the neocortex and, together with biochemistry, histochemistry and immunocytochemistry, have enabled precise localization of major neurotransmitters and neuroactive peptides in this structure (Bjorklund et al., 1978; Brown et al., 1979; Somogyi et al., 1981; Parnavelas and McDonald, 1983; Levitt et al., 1984; Peters and Jones, 1984, 1985; Jones and Peters, 1985; Morrison and Foote, 1986). In contrast, our knowledge about the distribution of neurotransmitter receptors and their relative concentrations in various areas of the neocortex until recently has been less detailed and less comprehensive. However, newly developed in vitro binding autoradiographic techniques (Young and Kuhar, 1979; Palacios et al., 1981b; Penney et al., 1981; Quirion et al., 1981; Rainbow et al., 1982; Unnerstall et al., 1984a, b; Wamsley and Palacios, 1984; Kuhar et al., 1986) now permit anatomical localization and quantification of a large number of neurotransmitter receptors at the level of cortical laminae and sublaminae.

As part of an ongoing investigation of the molecular, cellular, and functional organization of the primate neocortex, we have examined the binding pattern of 9 radioactive neurotransmitter ligands in the primary visual cortex, Brodmann's area 17, and in the extrastriate cortical area 18 , which borders area 17. The ligands were chosen on the basis of their high affinity, specificity, and adaptability to the in vitro binding procedure. Cortical area 17 and its border with area 18 were selected for the first detailed quantitative analysis because these areas are anatomically and physiologically distinct. The 6 basic layers of area 17, for example, can be further divided into several well-defined sublayers (Brodmann, 1905), each having characteristic cellular and synaptic density (O'Kusky and Colonnier, 1982), input and output relationships (Lund et al., 1975; Van Essen, 1986), and local neuronal circuitry (Gilbert and Wiesel, 1981; Lund, 1981; Rockland and Pandya, 1981; Somogyi et al., 1981; Rockland and Lund, 1983). Qualitative and quantitative differences in ligand binding are to be expected in various regions and layers of the cortex in view of the marked regional and laminar differences in the distribution of catecholamines (Bjorklund et al., 1978; Brown et al., 1979; McDonald et al., 1982; Morrison et al., 1982; Levitt et al., 1984; Morrison and Foote, 1986), ACh (Hedreen et al., 1984; Mesulam et al., 1984), and other neurotransmitters (Parnavelas and McDonald, 1983; Hendry et al., 1987). 
However, uniformity in ligand binding among regions and layers of the cortex is of comparable interest in deciphering its neurochemical interactions.

A considerable amount of data are already available on various receptors in the cortex of several species (Wise and Herkenham, 1982; Shaw et al., 1984; Pazos and Palacios, 1985; Wamsley, 1985; Hoyer et al., 1986a, b; Palacios et al., 1986; Shaw and Cynader, 1986; Kritzer et al., 1987). However, most of the previous research has not been focused on differences between cortical regions, and there exists as yet no quantitative data comparing distributions of multiple ligands in primates. In addition, the few studies available on the human cortex have not examined visual areas in detail, either qualitatively or quantitatively (e.g., Hoyer et al., 1986a, b). The rhesus monkey neocortex, particularly the visual system, is well suited for areal and laminar analysis because of the high degree of functional and anatomical specialization of its cytoarchitectonic subdivisions, and findings about receptor distribution in the primate order could have particular functional, developmental, and therapeutic implications for humans.

\section{Materials and Methods}

Tissue preparation. The brains of 3 adult ( 1 male, 2 females) and one 2-month-old male monkey (Macaca mulatta) were processed for the present study. Tissue from each animal was sectioned and assayed independently within 8-12 months of each other. The monkeys were anesthetized with Na-pentobarbital $(40 \mathrm{mg} / \mathrm{kg})$ and perfused with icecold PBS ( $\mathrm{pH} 7.4,1.25$ liters) followed by $0.1 \%$ paraformaldehyde containing increasing concentrations of sucrose in buffered saline: $500 \mathrm{ml}$ $0 \%$ sucrose, $500 \mathrm{ml} 5 \%$ sucrose, 1 liter $10 \%$ sucrose, $500 \mathrm{ml} 15 \%$ sucrose, 1 liter $20 \%$ sucrose. This light fixation allowed brain tissue to be sectioned more easily without affecting binding parameters (neither kinetic constants nor pharmacological profiles were affected; Bates and Gallagher, unpublished comparison of ligand binding properties of fixed and unfixed tissue sections from adult rhesus monkey cortex; Young and Kuhar, 1980a-c; Kuhar and Unnerstall, 1982). The brains were rapidly removed, blocked, and immersed in isopentane at $-30^{\circ} \mathrm{C}$ for approximately $5 \mathrm{~min}$ before storing at $-80^{\circ} \mathrm{C}$ until use. For autoradiography, $20 \mu \mathrm{m}$ sections were processed according to individual assay procedures. In each case, tissue sections were cut not more than 2 weeks prior to assay, mounted on acid-cleaned chrom alum-subbed slides, and stored at $-80^{\circ} \mathrm{C}$.

Binding assays. The 9 ligands selected for analysis in this study have been tested for both their affinity and specificity in numerous studies during the past few years, and further evidence of specificity is presented under Results. For all assays, slide-mounted tissue sections were incubated in increasing concentrations of radioligands. In some assays, preincubations were run to allow metabolism of endogenous ligands prior to incubation with labeled compounds. Parallel tissue sections were incubated with excess cold-displacing drugs to allow determination of nonspecific binding. For the most part, our methods follow established procedures (listed in Table 1). In all cases, association and dissociation times, and saturation kinetics were preliminarily defined in monkey tissue sections to optimize assay procedures for our laboratory conditions. We occasionally introduced minor modifications based on updated information from the literature or from our own results. Thus, cold prazosin (an $\alpha_{1}$-adrenergic antagonist) was used in the ${ }^{3} \mathrm{H}$-ketanserin assays of the last 2 animals based on evidence from a number of laboratories (Leysen et al., 1982; Smith et al., 1984; Lakoski and Aghajanian, 1985; Pazos et al., 1985) that some non-5-HT-displaceable binding occurs to $\alpha_{1}$-adrenoceptors. The iodinated ligands I'125-iodopindolol, a $\beta$-adrenergic antagonist (Rainbow et al., 1984b), and ${ }^{125} \mathrm{I}$ - HEAT, an $\alpha_{1}$-adrenergic antagonist (2- [B- (4-hydroxypheyl)-ethyl-amino-methyl] tetralune; Glossmann et al., 1981), were also used for comparison with tritiated compounds. Although absolute quantification was not carried out due to lack of reliable ${ }^{125}$ I standards, the binding profiles of iodinated ligands were compared with ${ }^{3} \mathrm{H}$ for relative binding distribution across layers in order to determine if white matter attenuation of lower energy beta emissions $\left({ }^{3} \mathrm{H}\right)$ was significant (Herkenham and Sokoloff, 1984; Rainbow et al., 1984a; Unnerstall et al., 1984b; Lidow et al., 1987).
This procedure did not affect the amount of specific binding of the ligand but increased the total level of radioactivity. Both defatting and overlay of tissue onto radioactive standards were used to estimate tritium quenching (Lidow et al., 1987). Only one sublayer (IVB) of area 17 in the visual cortex and the subcortical white matter was found to be significantly affected by such procedures. Except for the white matter, areas 18 and 19 were not affected. A correction factor was calculated from the 2 quenching experiments, and estimates of corrected values are shown as open columns in $B_{\max }$ histograms for this single cortical sublayer and adjacent white matter (Figs. 4 and 5).

Following assay, sections were rinsed and dried under a stream of cool dry air. They were kept in slide boxes with dessicant and stored overnight at $-80^{\circ} \mathrm{C}$. Sections were then placed in X-ray film cassettes with brain paste or commercial standards ( ${ }^{3} \mathrm{H}$-microscales, Amersham) against tritium-sensitive Ultrofilm (LKB, Inc., Gaithersburg, MD) at $4^{\circ} \mathrm{C}$ for varying exposure periods as listed in Table 1 . Following film exposure, tissue sections were stained with cresyl violet and coverslipped.

Quantitative densitometry. The intensity of receptor binding in tissue areas and layers was assessed using a computer-imaging system consisting of a DAGE-MTI series 68 video camera and video signal digitizing circuitry interfaced with a Digital VT100 computer. This system allows comparison of densities of exposed tritium-sensitive Ultrofilm (LKB, Gaithersburg, MD) with known labeled standards ( ${ }^{3} \mathrm{H}-$ microscales, Amersham, Chicago). In order to convert density measurements to molar amounts of bound ligand, standards were calibrated against tritium brain paste standards prepared using the radioligands employed in these studies and converted to milligram tissue equivalents (Rainbow et al., 1984a). In addition, comparison with optical density readings obtained from a photo print wheel allowed us to restrict our estimates to ranges below film saturation (below $0.80 \mathrm{D}$ ).

The method allows overlay of cresyl violet-stained tissue sections (the same ones used to generate the autoradiograms) on the film image in real time in order to make histological identification of specific cortical cell layers for each autoradiogram (Fig. 1). A background subtraction program allowed correction for possible nonuniform illumination of the film, and a Nikon macro zoom lens magnified the autoradiographic image to permit density measurements to be restricted to single cortical layers. Individual densitometric values were taken as the mean of 6 digitizations. In addition, each film with appropriate standards was read in at least 2 different computer sessions ( $\geq 2$ times). Values obtained across the different reading sessions were within $\pm 2 \%$, indicating the stability of the measurement system. Multiple densitometric readings were taken from at least 3 consecutive brain sections at each ligand concentration ( 5 concentrations of ligand per analysis). Values for nonspecific binding at each concentration were determined in adjacent sections and subtracted from the mean total bound. These values were analyzed by a computerized nonlinear curve-fitting program designed for analysis of ligand binding isotherms (Lundon-1, Lundon Software, 1984). $B_{\max }$ and $K_{d}$ values from resulting analyses were obtained for each animal and the mean value determined across animals (2-3 adults) for each layer and sublayer that could be identified cytoarchitectonically (Fig. 2). In cases where Scatchard-Rosenthal analysis failed to define a single site $(R<0.85)$, data are shown as relative distributions of specific binding, averaged across animals for a single ligand concentration. $K_{d}$ values were calculated from optical density measurements of tritiumsensitive Ultrofilm exposed to labeled tissue sections. Comparisons were made across cortical layers, across areas, and across methods, i.e., values obtained in autoradiograms were compared to those obtaincd by liquid scintillation counting of whole-brain sections assayed in parallel for each of the binding assays described. The pattern of receptor distribution in the infant monkey was qualitatively similar to that in the adult monkeys. However, since the receptors may not have been fully expressed in the immature neurons of the infant monkey, the quantitative data and all illustrations in this article are based exclusively on the adult cases.

\section{Results}

Each radioligand is distributed in a characteristic pattern in both the striate (area 17) and extrastriate areas (18 and 19) of the visual cortex. The pattern of distribution of each ligand in each area is described below, and quantitative data are presented for the 2-3 most completely analyzed adult animals. Fluctuations in $K_{d}$ values calculated for each ligand by Scatchard analysis 


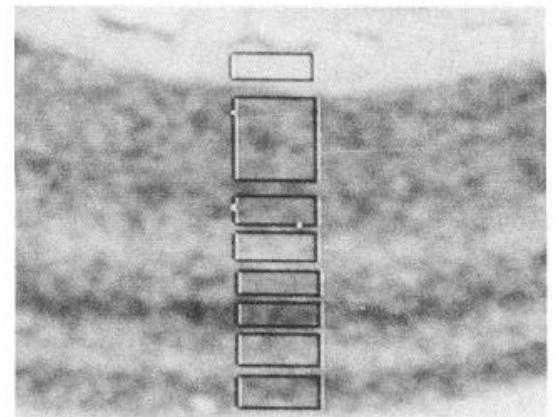

A
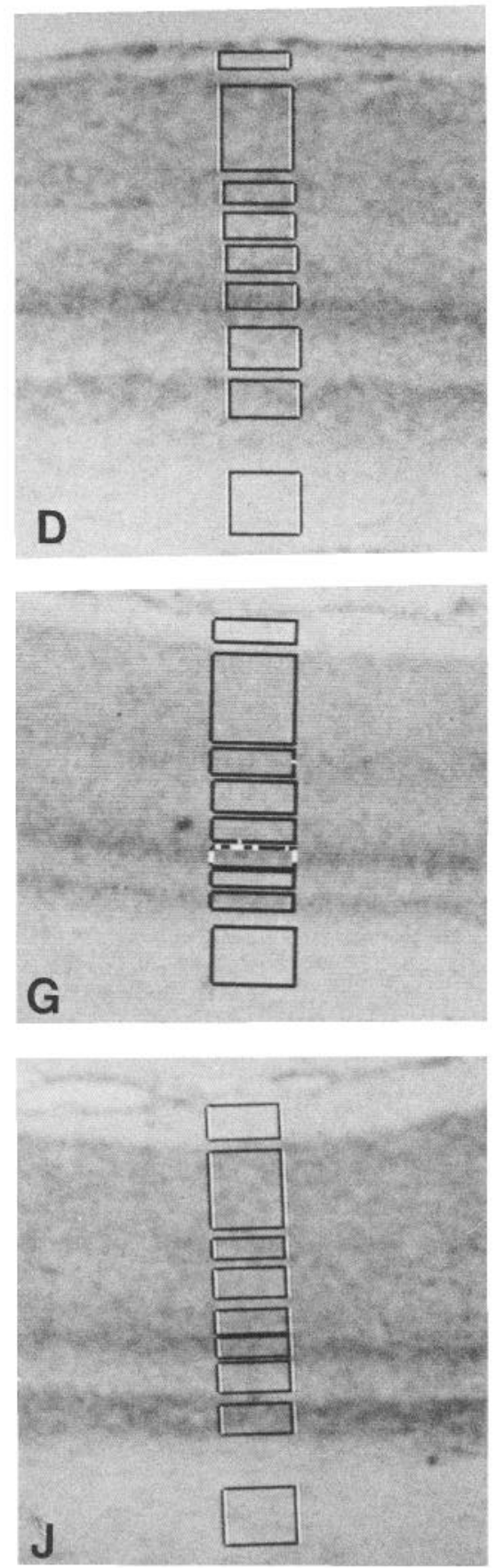

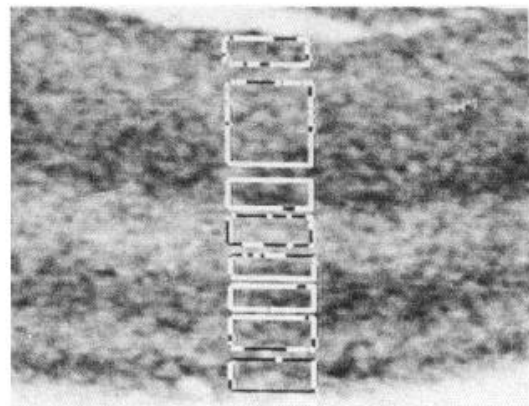

B
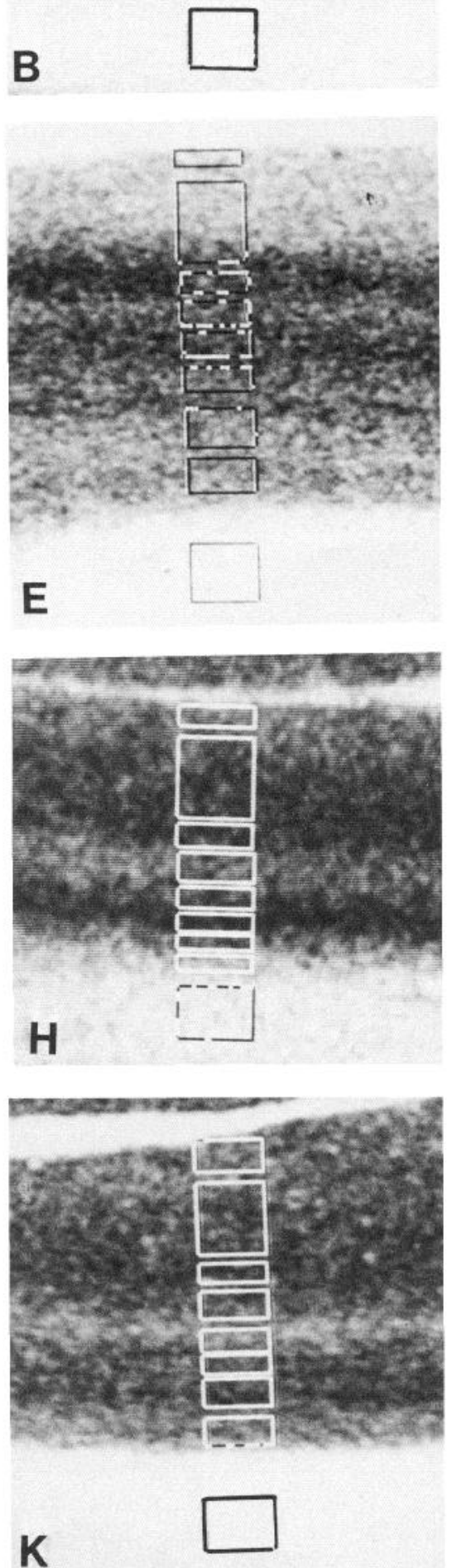
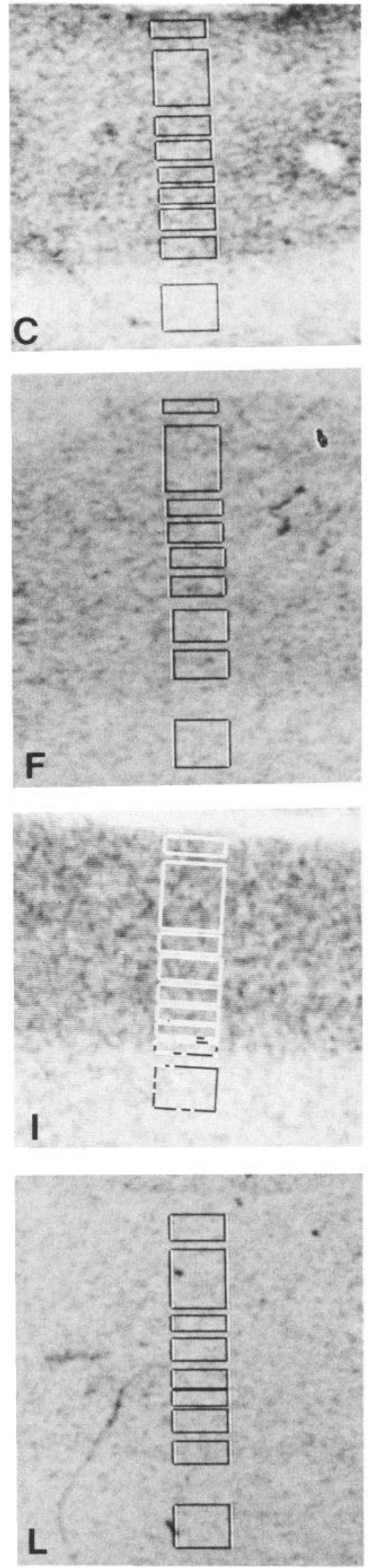

Figure 1. Photographs of video images taken from the TV monitor to illustrate quantitative densitometry. The first column $(A-J)$ shows a digitized computer-generated image of the primary visual cortex (area 17) obtained from cresyl violet-stained sections. The second column $(B-K)$ shows Ultrofilm exposed to the radioactivity of these sections incubated with ${ }^{3} \mathrm{H}$-clonidine $(B),{ }^{3} \mathrm{H}-5$-hydroxytryptamine $(E)$, ${ }^{3} \mathrm{H}$-ketanserin $(H)$, and ${ }^{3} \mathrm{H}$ - 
from densitometric measurements on a layer-by-layer basis in areas 17 and 18 were within the range of affinities reported for various ligands in membrane homogenates (Table 2). Moreover, there were no statistically significant differences in $K_{d}$ values between layers or areas. Furthermore, white matter labeling was either at or slightly above background for each ligand; however, correcting for white matter quenching did increase binding in this region for a few ligands (see open bars on histograms in Figs. 4 and 5). Although the intensity of labeling was somewhat variable from case to case, the basic pattern of film density was remarkably similar in all 4 cases. Differences between the total labeling, nonspecific labeling, and $B_{\max }$ values are discussed only in instances where a significant discrepancy in relative intensity between ligand-incubated and control sections was encountered.

\section{${ }^{3} \mathrm{H}$-clonidine}

This ligand and its para-amino analog (Young and Kuhar, 1980a, b) have been used extensively to map $\alpha_{2}$-adrenoceptors in the rodent brain. Our data show that in the primate visual cortex, tritiated clonidine binding was characterized by a single site of high affinity with saturability and appropriate pharmacology associated with $\alpha_{2}$-adrenergic adrenoceptors (oxymetazoline $>$ $\mathrm{NE}>$ phenylephrine). An example of saturation binding and the resulting linear $(R=0.96)$ Scatchard plot for a single sublayer (IVC-beta, area 17) are shown in Figure 2. Such analysis is representative of analyses in other layers and for other ligands as described below.

Sections incubated with ${ }^{3} \mathrm{H}$-clonidine (Figs. $1 \mathrm{~B}, 3 \mathrm{~A}$ ) displayed the most elaborate layering pattern in the striate cortex, clearly revealing each cortical layer and sublayer that is recognized with classical Nissl stain in this cytoarchitectonic area (Fig. 1 $A$ ). The most prominent feature of the distribution in autoradiograms was the presence of 4 dark bands situated in layers I, IV $\Lambda, I V C$ beta, and the upper stratum of layer VI. Intermediate level binding was localized in layers II, III, IVC-alpha, and the lower stratum of VI, while 2 low-density bands were situated in layers IVB and $\mathrm{V}$.

Quantitative densitometric analysis confirmed visual analysis but also pointed up instructive differences. For example, as evident from histograms in Figure $4 A, B_{\max }$ values for the densely labeled layers IVC-beta and VI were greater than the more lightly labeled layers IVC-alpha and V. The distribution and intensity of labeling were similar in all 3 adult specimens except in layer I, which was much more densely labeled in one animal (maximum total binding of 103 vs 32 and $24 \mathrm{fmol} / \mathrm{mg}$ tissue for 2 additional adult cases). The control autoradiogram specimen from this animal shows that a considerable amount of the radioactivity localized in layer I was due to nonspecific binding (compare Figs. $1 B$ and $1 C$ ). This difference is clearly depicted in the calculations of specific $B_{\max }$ values, which reveal that the dark band in layer $\mathrm{I}$ is indeed nonspecific (Fig. 4A). However, the other 3 dark bands in the cortex correspond to the highest concentrations of specific binding of clonidine in all 3 adults,

\section{${ }^{3} \mathrm{H}$-Clonidine Binding $\mathrm{IVC}_{\mathrm{B}}$ Area 17}

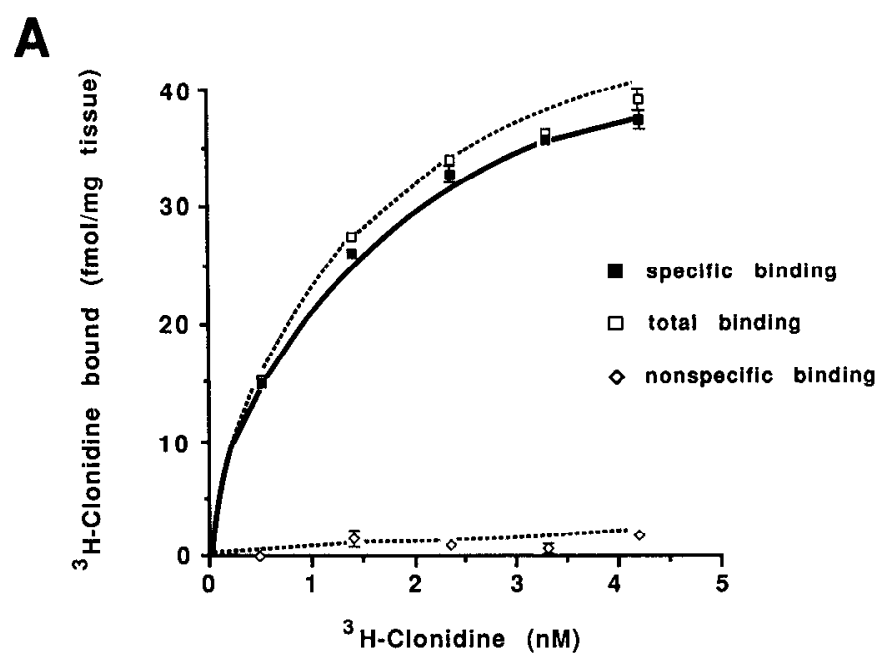

B

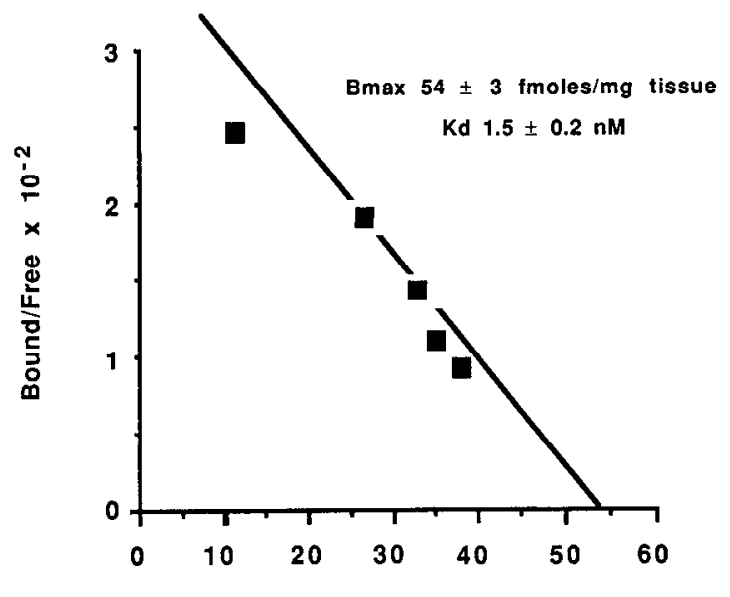

${ }^{3} \mathrm{H}$-Clonidine Specific bound (fmoles/mg tissue)

Figure 2. A, Saturation binding of ${ }^{3} \mathrm{H}$-clonidine to layer IVC-beta of the calcarine fissure in area 17 of the occipital cortex in a representative monkey. Consecutive brain sections were labeled as described in the text with various concentrations of ${ }^{3} \mathrm{H}$-clonidine and apposed to LKB Ultrofilm for $60 \mathrm{~d}$ to generate autoradiograms. Nonspecific binding was defined as the labeling in the presence of $100 \mathrm{nM}$ NE. Densitometric readings were taken in at least 3 consecutive brain sections at each concentration of ligand with or without NE and converted into molar levels of ${ }^{3} \mathrm{H}$-clonidine by reference to tritium microscales (AmershanScarle) and ${ }^{3} \mathrm{H}$-clonidine brain-mash standards as described in the text. $B$, Scatchard plot of the specific binding of ${ }^{3} \mathrm{H}$-clonidine in this representative monkey is shown yielding a single site with $B_{\max }$ of $54 \pm 3$ $\left( \pm\right.$ SEM) $\mathrm{fmol} / \mathrm{mg}$ tissue and a dissociation constant $\left(K_{d}^{\prime}\right)$ of $1.5 \pm 0.2$ nM as computed by a nonlinear curve-fitting program (Lundon Software Inc.). Similar $B_{\max }$ data from 2 adult animals were averaged and are displayed in Figure $4 A$.

flunitrazepam $(K)$. The third column $(C-L)$ shows the Ultrofilm exposed to the adjacent section incubated by the appropriate displacing drug as control. Each sublayer and the subjacent white matter are first identified in cresyl violet-stained sections and selected regions delineated by a rectangle. Then the section is removed from the camera, and films from the receptor and its displacing agent are put in register with the image of the cresyl violet section that is retained on the screen. Following alignment, the cresyl violet image is removed and the computer generates a readout of film density, expressed as $B_{\max }$ and $K_{d}$ values, as described in the text. 
Table 1. Summary of ligands and procedures

\begin{tabular}{|c|c|c|c|c|c|c|c|c|}
\hline Ligand & $\begin{array}{l}\text { Conc. } \\
\text { (nM) }\end{array}$ & Site labeled & Blank & Protocol & Buffer & Time & Temp. & $\begin{array}{l}\text { Exposure } \\
\text { time }\end{array}$ \\
\hline \multirow[t]{3}{*}{$\begin{array}{l}{ }^{3} \mathrm{H} \text {-Clonidine } \\
\text { (SA } 49.8 \mathrm{Ci} / \mathrm{mm})\end{array}$} & \multirow[t]{3}{*}{$\begin{array}{l}0.5,1.5,2.5,3.5 \\
\quad 4.5\end{array}$} & \multirow[t]{3}{*}{$\mathrm{NE} \alpha_{2}$} & \multirow[t]{3}{*}{$\mathrm{NE}(100 \mu \mathrm{M})$} & $\begin{array}{l}\text { Pre-incuba- } \\
\text { tion }\end{array}$ & $\begin{array}{l}0.17 \text { м Tris- } \mathrm{HCl} \\
5 \mathrm{~mm} \text { EDTA } \\
(\mathrm{pH} 7.6)\end{array}$ & $30 \mathrm{~min}$ & RT & \multirow[t]{3}{*}{4 months } \\
\hline & & & & Incubation & $\begin{array}{l}0.17 \mathrm{M} \text { Tris- } \mathrm{HCl} \\
1 \mathrm{mM} \mathrm{MnCl}_{2} \\
0.001 \% \text { ascorbic acid } \\
\text { (pH 7.6) }\end{array}$ & $60 \mathrm{~min}$ & RT & \\
\hline & & & & Rinse & $\begin{array}{l}0.17 \mathrm{M} \text { Tris-HCl } \\
(\mathrm{pH} 7.0)\end{array}$ & $2 \times 5 \min$ & $4^{\circ} \mathrm{C}$ & \\
\hline \multirow[t]{3}{*}{$\begin{array}{l}\text { Prazosin } \\
(19.8 \mathrm{Ci} / \mathrm{mm})\end{array}$} & \multirow{3}{*}{\multicolumn{2}{|c|}{$0.2,0.4,0.6,0.8,1.0 \mathrm{NE} \alpha_{1}$}} & \multirow[t]{3}{*}{$\begin{array}{l}\text { Phenylephrine } \\
(100 \mu \mathrm{M})\end{array}$} & $\begin{array}{l}\text { Pre-incuba- } \\
\text { tion }\end{array}$ & $\begin{array}{l}0.17 \text { м Tris-HCl } \\
(\mathrm{pH} 7.1)\end{array}$ & $30 \mathrm{~min}$ & $4^{\circ} \mathrm{C}$ & \\
\hline & & & & Incubation & Same & $70 \mathrm{~min}$ & $4^{\circ} \mathrm{C}$ & 2 months \\
\hline & & & & Rinse & Same & $2 \times 5 \mathrm{~min}$ & $4^{\circ} \mathrm{C}$ & \\
\hline \multirow[t]{2}{*}{$\begin{array}{l}{ }^{125} \text { I-Iodopindolol } \\
(2200 \mathrm{Ci} / \mathrm{mm})\end{array}$} & \multirow[t]{2}{*}{$10,20,50,100,150$} & \multirow[t]{2}{*}{ NE $\beta$} & \multicolumn{2}{|c|}{$\begin{array}{l}\text { Isoproterenol Incubation } \\
(500 \mu \mathrm{M}) \\
\text { Metaprolol } \\
\left(\beta_{1} 0.17,0.9,2 \mu \mathrm{M}\right)\end{array}$} & $\begin{array}{l}0.17 \mathrm{~m} \text { Tris- } \mathrm{HCl} \\
10 \mathrm{mM} \mathrm{MgCl}_{2} \\
20 \mu \mathrm{M} \text { phentolamine } \\
(\mathrm{pH} 7.7 \text { ) }\end{array}$ & $30 \mathrm{~min}$ & RT & \multirow[t]{2}{*}{$18 \mathrm{hrs}$} \\
\hline & & & $\begin{array}{l}\text { Zinterol } \\
\left(\beta_{2} 0.03,0.5,1 \mu \mathrm{M}\right)\end{array}$ & Rinse & $\begin{array}{l}0.17 \text { м Tris- } \mathrm{HCl} \\
20 \mu \mathrm{M} \text { phentolamine } \\
(\mathrm{pH} 7.0)\end{array}$ & $2 \times 5 \min$ & $4^{\circ} \mathrm{C}$ & \\
\hline \multirow[t]{2}{*}{$\begin{array}{l}\text { QNB } \\
(39.4 \mathrm{Ci} / \mathrm{mm})\end{array}$} & \multirow[t]{2}{*}{$\begin{array}{l}0.15,0.3,0.6,1.2 \\
\quad 2.4\end{array}$} & \multirow[t]{2}{*}{$\begin{array}{l}\text { ACh mus- } \\
\text { carinic }\end{array}$} & \multirow[t]{2}{*}{ Atropine $(1 \mu \mathrm{M})$} & Incubation & $\begin{array}{l}0.17 \text { м Tris- } \mathrm{HCl} \\
(\mathrm{pH} 7.4)\end{array}$ & $120 \mathrm{~min}$ & RT & \multirow[t]{2}{*}{14 days } \\
\hline & & & & Rinse & Same & $2 \times 5 \min$ & $4^{\circ} \mathrm{C}$ & \\
\hline \multirow[t]{2}{*}{$\begin{array}{l}5-\mathrm{HT} \\
(24.3 \mathrm{Ci} / \mathrm{mM})\end{array}$} & \multirow[t]{2}{*}{$1,2,4,8,16$} & \multirow[t]{2}{*}{$5-\mathrm{HT}_{1}$} & \multirow[t]{2}{*}{ 5-HT $(1 \mu \mathrm{M})$} & Incubation & $\begin{array}{l}0.17 \mathrm{M} \text { Tris- } \mathrm{HCl} \\
0.4 \mathrm{mM} \mathrm{CaCl}_{2} \\
10 \mu \mathrm{M} \text { pargyline } \\
1 \mu \mathrm{M} \text { fluoxetine } \\
0.1 \% \text { ascorbic acid } \\
(\mathrm{pH} 7.7 \text { ) }\end{array}$ & $60 \mathrm{~min}$ & RT & \multirow[t]{2}{*}{2 months } \\
\hline & & & & Rinse & Same (pH 7.1) & $5 \times 60 \mathrm{sec}$ & $4^{\circ} \mathrm{C}$ & \\
\hline \multirow[t]{3}{*}{$\begin{array}{l}\text { Ketanserin } \\
(77 \mathrm{Ci} / \mathrm{mm})\end{array}$} & \multirow[t]{3}{*}{$0.5,1,2,3,4$} & \multirow[t]{3}{*}{$5-\mathrm{HT}_{2}$} & \multirow[t]{3}{*}{$\begin{array}{l}\text { Methysergide } \\
(10 \mu \mathrm{M})\end{array}$} & $\begin{array}{l}\text { Pre-incuba- } \\
\text { tion }\end{array}$ & $\begin{array}{l}50 \mathrm{mM} \text { Tris-Hcl } \\
0.1 \mu \mathrm{M} \text { prazosin } \\
(\mathrm{pH} \mathrm{7.7)}\end{array}$ & $30 \mathrm{~min}$ & RT & \\
\hline & & & & Incubation & Same & $20 \mathrm{~min}$ & RT & 3 weeks \\
\hline & & & & Rinse & Same (pH 7.1) & $5 \times 60 \mathrm{sec}$ & $4^{\circ} \mathrm{C}$ & \\
\hline \multirow[t]{3}{*}{$\begin{array}{l}\text { Flunitrazepam } \\
(92.3 \mathrm{Ci} / \mathrm{mm})\end{array}$} & \multirow[t]{3}{*}{$1,2,4,8,16$} & \multirow[t]{3}{*}{$\begin{array}{l}\text { Benzodiazc- } \\
\text { pine }\end{array}$} & \multirow[t]{3}{*}{$\begin{array}{l}\text { Clonazcpam } \\
\qquad(1 \mu \mathrm{M})\end{array}$} & $\begin{array}{l}\text { Prc-incuba- } \\
\text { tion }\end{array}$ & $\begin{array}{l}0.17 \text { M Tris- } \mathrm{HCl} \\
(\mathrm{pH} \mathrm{7.4)}\end{array}$ & $10 \mathrm{~min}$ & $4^{\circ} \mathrm{C}$ & \\
\hline & & & & Incubation & Same & $40 \mathrm{~min}$ & $4^{\circ} \mathrm{C}$ & 2 weeks \\
\hline & & & & Rinse & Same & $5 \times 20 \mathrm{sec}$ & $4^{\circ} \mathrm{C}$ & \\
\hline \multirow[t]{3}{*}{$\begin{array}{l}\text { Muscimol } \\
(11.5 \mathrm{Ci} / \mathrm{mm})\end{array}$} & \multirow[t]{3}{*}{$2.5,5,7.5,10,20$} & $\mathrm{GABA}_{\mathrm{a}}$ & GABA (10 mM) & $\begin{array}{l}\text { Pre-incuba- } \\
\text { tion }\end{array}$ & $\begin{array}{l}50 \mathrm{~mm} \text { Tris-citrate } \\
(\mathrm{pH} 7.1)\end{array}$ & $20 \mathrm{~min}$ & $4^{\circ} \mathrm{C}$ & \\
\hline & & & & Incubation & Same & $40 \mathrm{~min}$ & $4^{\circ} \mathrm{C}$ & 6 weeks \\
\hline & & & & Rinse & Same & $2 \times 15 \mathrm{sec}$ & $4^{\circ} \mathrm{C}$ & \\
\hline $\begin{array}{l}\text { Spiperone } \\
(22.7 \mathrm{Ci} / \mathrm{mm})\end{array}$ & $0.4,0.7,1.2,2.4,6.6$ & $6 \mathrm{DA}$ & $(+)$-Butaclamol & Incubation & $\begin{array}{l}0.17 \mathrm{M} \text { Tris-HCl } \\
120 \mathrm{mM} \mathrm{NaCl} \\
5 \mathrm{mM} \mathrm{KCl} \\
2 \mathrm{mM} \mathrm{CaCl}_{2} \\
1 \mathrm{mM} \mathrm{MgCl}_{2} \\
0.001 \% \text { ascorbic acid } \\
\text { (pH 7.7) }\end{array}$ & $30 \mathrm{~min}$ & RT & 2 months \\
\hline & & & & Rinse & $\begin{array}{l}0.17 \text { м Tris-HCl } \\
(\mathrm{pH} 7.1)\end{array}$ & $5 \times 60 \mathrm{sec}$. & $4^{\circ} \mathrm{C}$ & \\
\hline
\end{tabular}



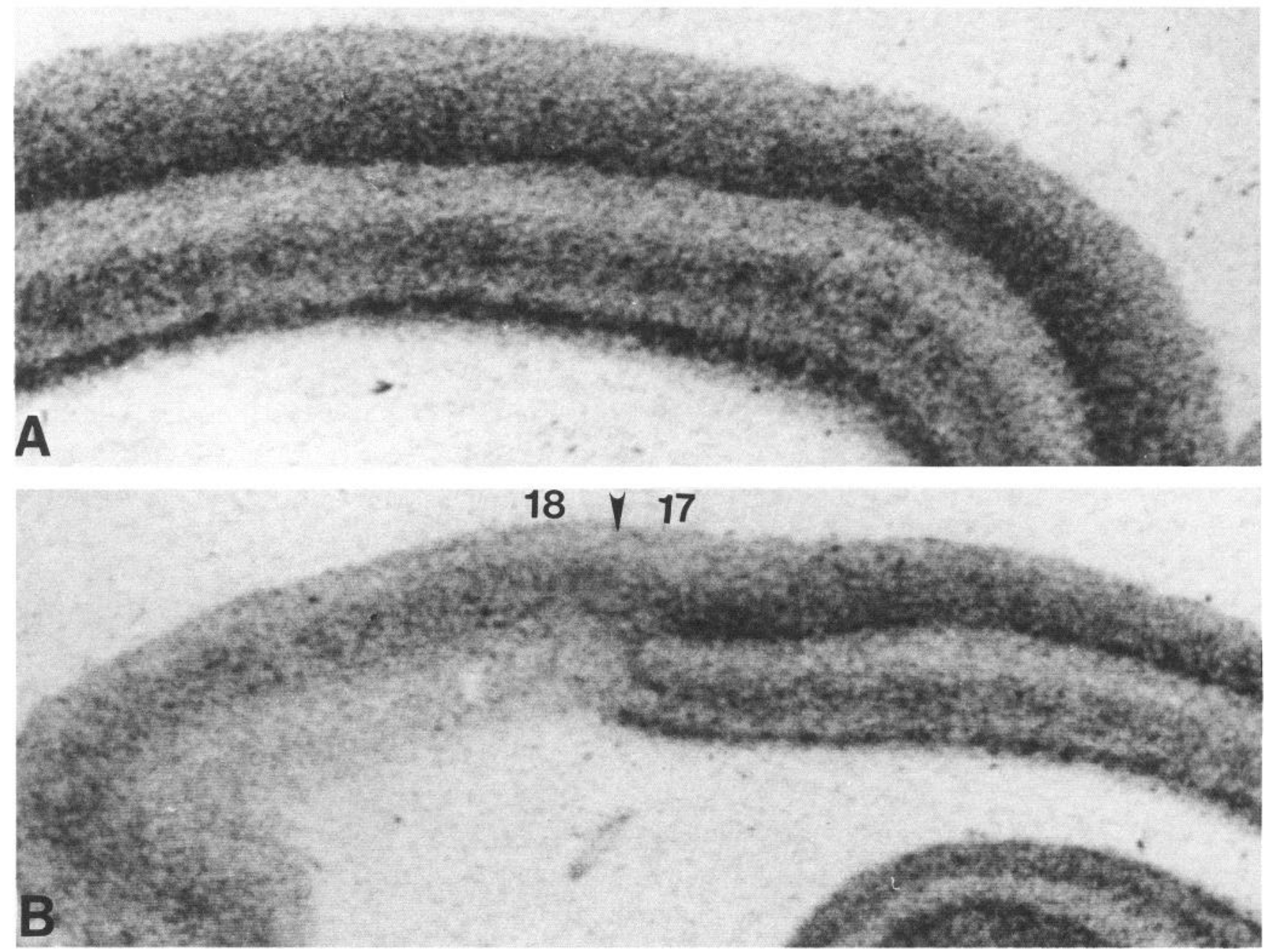

Figure 3. A, Laminar distribution of ${ }^{3} \mathrm{H}$-clonidine binding in the striate cortex of the adult rhesus monkey. Video image of the autoradiogram shows densely labeled layers IVA, IVC-beta, and VI. $B$, Distribution of the same ligand at the border between areas 17 and 18 .

as well as in the infant monkey. $B_{\max }$ values show that binding in IVB exceeds the binding in layer $\mathrm{V}$, especially after correcting for tissue quenching of tritium. Our data indicate that specific binding of ligands is more reproducible than the total binding. Further, the observed discrepancy indicates that the data from a single case may give spurious results. In general, nonspecific binding and variability in film density due to artifacts occur most often in layer I.

Examination of the autoradiograms at low magnification reveals that the distribution of ${ }^{3} \mathrm{H}$-clonidine in the extrastriate cortex is substantially different than in the striate cortex both qualitatively and quantitatively (Fig. $3 B$ ). First, the density of binding sites $\left(B_{\max }\right)$ in area 18 was about one-half that of area 17 (Fig. 4B). In addition, all the dark bands that characterize area 17 were absent in area 18 , and only a single, broad, intermediate density band corresponding to layers II-IV was visible (Figs. $4, A, B ; 10 ; 11$ ). Thus, the intricate, distinct, and contrasting laminar pattern that characterizes area 17 was absent from area 18 in autoradiograms (Fig. $3 B$ ) of total labeling and in the $B_{\max }$ data (Fig. 4, $A, B$ ). Since the same coronal sections across the occipital lobe contained both areas 17 and 18, the
Table 2. $K_{d}$ values ( \pm SD) for binding of ligands across cortical layers in areas 17 and 18 of 2-3 monkeys assayed independently

\begin{tabular}{lll} 
& \multicolumn{2}{l}{$K_{d}(\mathrm{~nm})^{a}$} \\
\cline { 2 - 3 } Ligand & Area 17 & Area 18 \\
\hline${ }^{3} \mathrm{H}-$-Clonidine & $1.6 \pm 0.6$ & $1.5 \pm 0.6$ \\
${ }^{3} \mathrm{H}-$ Prazosin & $0.6 \pm 0.4$ & $0.4 \pm 0.3$ \\
125-Iodopindolol & $0.1 \pm 0.1$ & $0.1 \pm 0.1$ \\
${ }^{3} \mathrm{H}-$-QNB & $0.4 \pm 0.1$ & $0.3 \pm 0.1$ \\
${ }^{3} \mathrm{H}-5-\mathrm{HT}$ & $2.4 \pm 0.4$ & $1.7 \pm 0.8$ \\
${ }^{3} \mathrm{H}-$ Ketanserin & $2.9 \pm 2.4$ & $2.5 \pm 0.9$ \\
${ }^{3} \mathrm{H}-$ Flunitrazepam & $2.5 \pm 0.3$ & $2.4 \pm 0.2$ \\
${ }^{3} \mathrm{H}-$ Muscimol & $1.8 \pm 1.2$ & $1.7 \pm 0.6$ \\
${ }^{3}$ H-Spiperone & $3.1 \pm 1.6$ & $2.1 \pm 2.0$
\end{tabular}

Apparent affinities $\left(K_{d}\right.$ 's) were determined by Scatchard analysis of densitometric readings from autoradiograms generated by equilibrium saturation binding to visual cortical slices.

${ }^{a}$ ANOVA comparisons of $K_{d}$ values within areas 17 and 18 showed no statistically significant differences in apparent affinity between cortical layers. In contrast, ANOVA comparisons of $B_{\max }$ data between cortical layers did reveal significant differences (Figs. 4 and 5). 

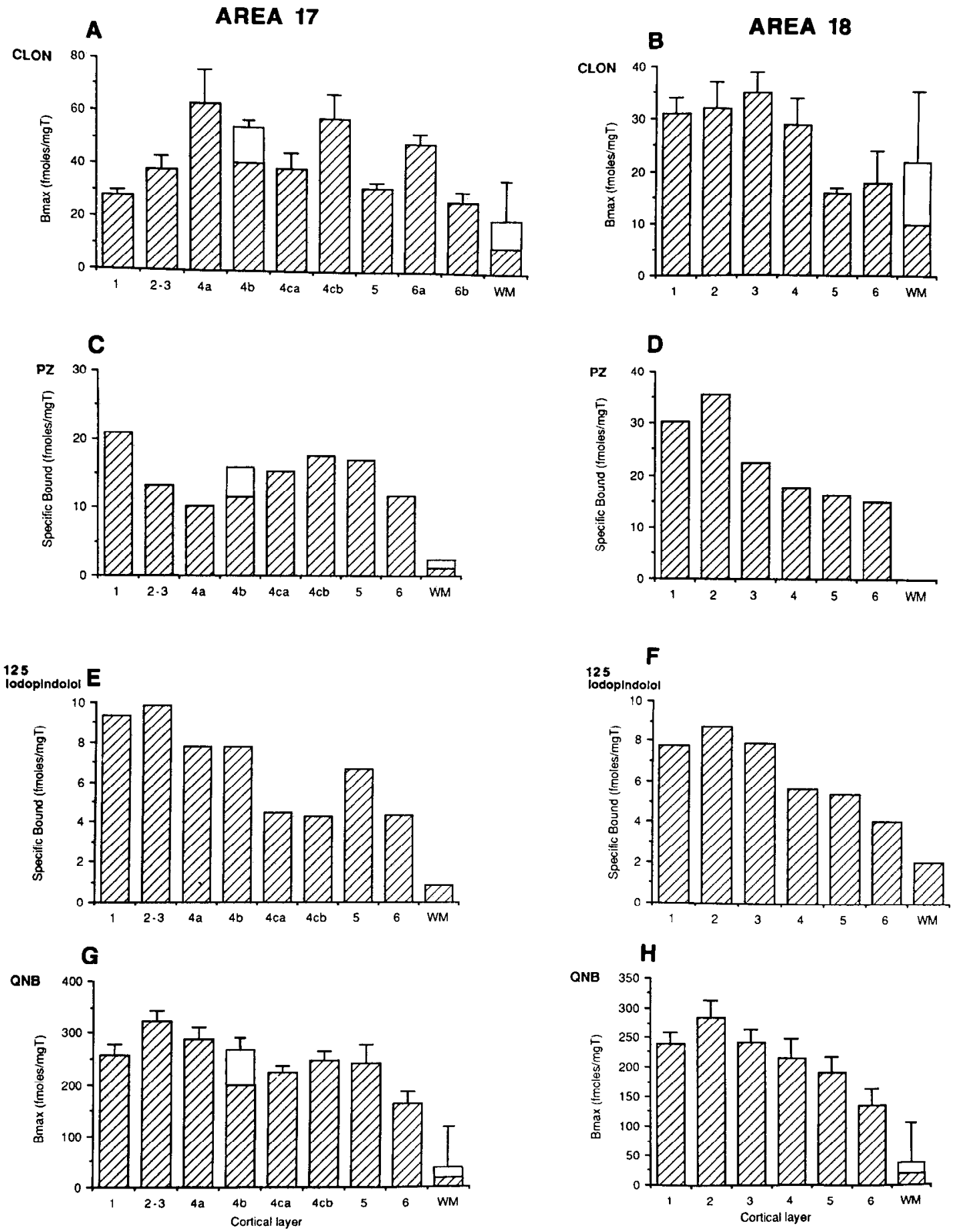

Figure 4. $B_{\max }$ and specific binding data computed for areas 17 and 18 of ligands by layer. Layer IVB of area 17 was found to be significantly affected by white matter attenuation of tritium emissions. Therefore, a correction factor (Lidow et al., 1987) has been introduced, indicated by open columns added to the observed density. $A$ and $B,{ }^{3} \mathrm{H}$-clonidine, average $( \pm \mathrm{SEM})$ of 2 adult cases. $C$ and $D,{ }^{3} \mathrm{H}$-prazosin showing relative distribution of label averaged for 2 adult cases when sections were incubated at a single $(0.6 \mathrm{nM})$ concentration of ligand. $E$ and $F$, ${ }^{12 s}$ I-Iodopinolol representing relative distribution of specific binding averaged for 2 adult animals when sections were incubated at a single (0.1 nM) concentration of ligand. $G$ and $H,{ }^{3} \mathrm{H}-\mathrm{QNB} B_{\max }$ values averaged over 3 adult cases (infant also showed similar binding profile and density of sites).

differences between them could not be due to processing conditions, which were identical for each area.

As a result of the changes in binding distribution, the borderline between areas 17 and 18 was abrupt and visually striking in autoradiograms (Fig. $3 B$ ). In contrast, the more rostral border between areas 18 and 19 could not be detected in the autora- diograms, indicating that this ligand does not delineate subdivisions between subareas of the extrastriate cortex. The white matter subjacent to both the striate and extrastriate cytoarchitectonic areas appeared only lightly labeled, but quenching correction indicates significant white matter binding $(20 \mathrm{fmol} / \mathrm{mg}$ tissue) for this ligand (Figs. 3; 4, $A, B$ ). 

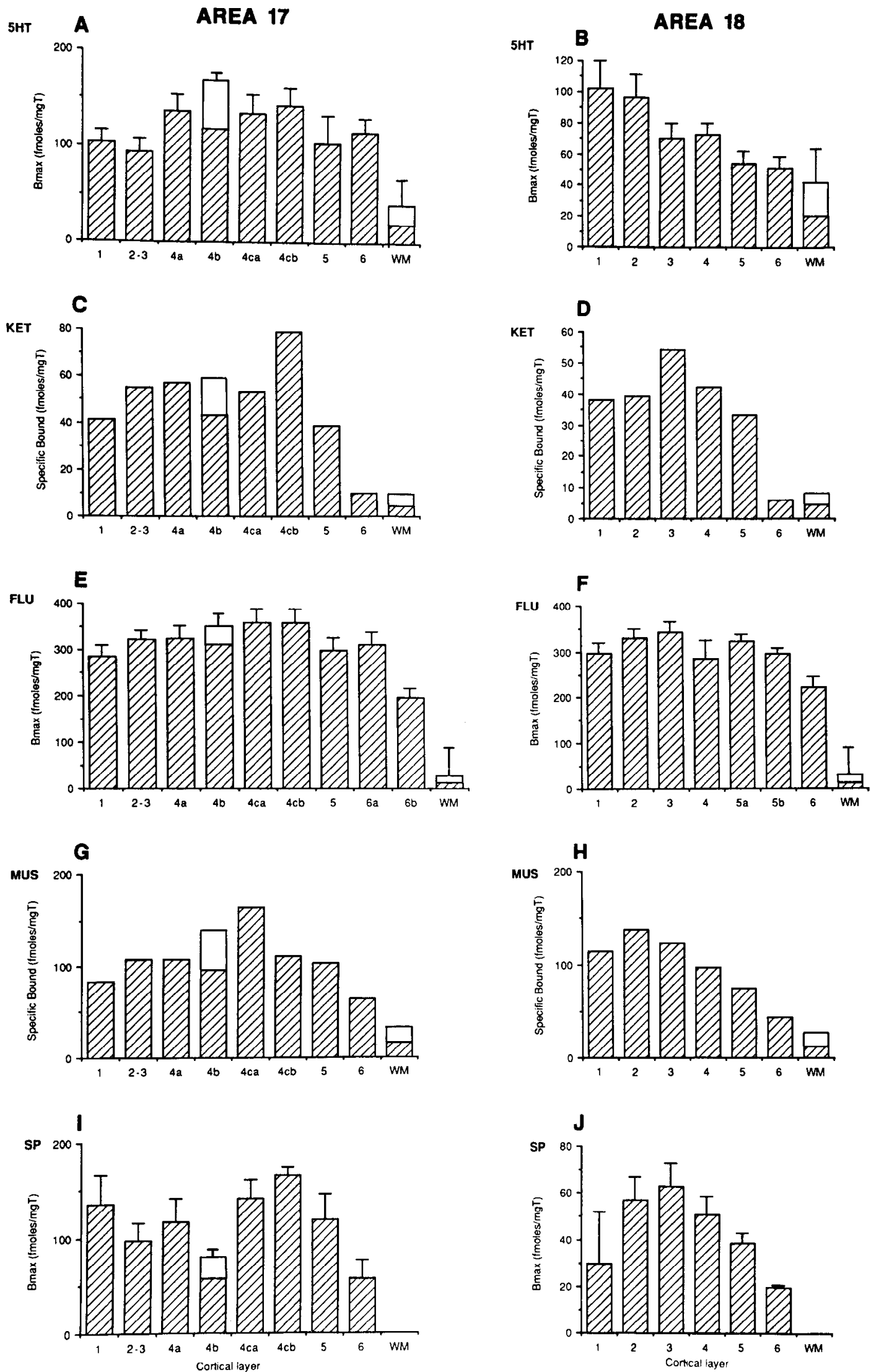

Figure 5. $\quad \mathrm{B}_{\max }$, specific binding data computed for areas 17 and 18 of ligands analyzed by layer. As in Figure 4, layer IVB of area 17 has been corrected for tissue quenching. $A$ and $B,{ }^{3} \mathrm{H}-5-\mathrm{HT} B_{\max }$ averaged for 3 adult cases $( \pm \mathrm{SEM}) . C$ and $D$, Specific ${ }^{3} \mathrm{H}-$ ketanserin binding at a single $(2.5$ nM) concentration averaged for 2 adult cases. $E$ and $F,{ }^{3} \mathrm{H}$-flunitrazepam $B_{\max }$ values averaged for 2 adult cases ( \pm SEM). $G$ and $H$, Specific ${ }^{3} \mathrm{H}$ muscimol binding at a single $(20 \mathrm{nM})$ concentration averaged for 2 adult cases. $I$ and $J,{ }^{3} \mathrm{H}$-spiperone $B_{\max }$ values for 2 adult cases ( \pm SEM). 


\section{${ }^{3} H$-prazosin}

Films exposed to the sections incubated with prazosin, which binds to $\alpha_{1}$-adrenergic receptors, displayed a considerably less intricate layering pattern than those exposed to sections incubated with clonidine. The $\alpha_{1}$ subtype of the noradrenergic (NE) receptor is thought to mediate many of the postsynaptic actions of NE in the brain (Rogawski and Aghajanian, 1980) and prazosin, the $\alpha_{1}$-antagonist, has been shown to selectively block any actions at this receptor (e.g., Menkes et al., 1981). ${ }^{3} \mathrm{H}-$ prazosin has been used in autoradiographic procedures to label $\alpha_{1^{-}}$ receptors (Dashwood, 1983; Rainbow and Biegon, 1983). In the present study, in addition to tritiated prazosin, we also employed ${ }^{125}$ I-HEAT (Glossmann et al., 1981; Jones et al., 1983) in selected sections in order to circumvent white matter attenuation of tritium emissions (Herkenham and Sokoloff, 1984; Rainbow ct al., 1984a; Unncrstall ct al., 1984b). Although the ${ }^{125}$ I-HEAT autoradiograms were not examined quantitatively, the overall binding profile was similar to the pattern of binding observed using tritiated prazosin, indicating that the pattern of binding with ${ }^{3} \mathrm{H}$-prazosin (described below) could not be attributed solely to white matter attenuation.

Films of sections incubated with ${ }^{3} \mathrm{H}$-prazosin consistently contained 2 broad bands of intermediate intensity situated in layers I, IVC-alpha, and IVC-beta through V, and a thin, weakly labeled stripe corresponding to sublayers IVA and IVB. The remainder of the cortex was moderately and uniformly labeled (Fig. 6A). This pattern, which was confirmed by the quantitative measurements of specific binding in each layer (Fig. 4C), was present throughout the striate cortex, including the calcarine fissure. However, correction for white matter attenuation of tritium did reveal the binding density of sublayer IVB to be equivalent to adjacent sublayer IVC. Labeling was quite different in area 18 (Fig. $6 \mathrm{~B}$ ). In this cytoarchitectonic field, the light intensity band in layer IV was lost and, except for the higher binding in layer I and particularly upper layer II, the rest of the cortex was essentially uniformly labeled (Figs. 4D, 6B). Although the borderline between areas 17 and 18 was less pronounced in autoradiograms for prazosin than for clonidine, it was readily detectable (Fig. $6 B$ ). Likewise, the border between areas 18 and 19 was not discernible. White matter subjacent to both striate and extrastriate areas was slightly above the background level, but the intensity of label was much less than that in any layer of either cortical area (approximately $2 \mathrm{fmol} / \mathrm{mg}$ tissue).

\section{${ }^{225}$ I-iodopindolol (IPN)}

To localize the $\beta$-adrenergic receptor, we used the iodinated antagonist iodopindolol (Rainbow et al., 1984b). Beta-receptor subtypes have been distinguished pharmacologically $\left(\beta_{1}\right.$ and $\left.\beta_{2}\right)$ using selective agonists and antagonists (Minneman et al., 1979; Rainbow et al. 1984b). Previous membrane and autoradiographic studies demonstrate predominantly $\beta_{1}$ binding (85-90\%) in the visual cortex of rodents (McDonald et al., 1982; Rainbow et al., 1984b). The quantitative autoradiographic techniques used in the present study do not discriminate the specific subtype components of $\beta$-adrenergic binding. However, preliminary results from our laboratory using $\beta_{1}$-selective metoprolol and $\beta_{2}$ selective zinterol as displacing agents (Minneman et al., 1979) suggest that $\beta_{1}$ sites predominate in the primate visual cortex as well (data not shown).
In general, our results indicate that binding of IPN was generally low in both striate and extrastriate areas (Fig. 4, E, F). Labeling in area 17 was uniquely low in layer IVC-alpha and IVC-beta for this ligand, giving the appearance of denser bands on either side-that is, denser for layers IVA, IVB and V. The highest labeling for this ligand was found in layers II and III (Fig. 6C). Examination of the quantitative data indicates that the supragranular layers were slightly more radioactive than the infragranular layers (Fig. $4 E$ ). Comparison of the total binding illustrated in Figure 6 and histograms in Figure $4 F$ shows that the dense band in layer IVA is due to nonspecific labeling. This was confirmed in 2 specimens incubated with IPN and provides another example of nonspecific binding that was corrected by subtraction of the dense stripe obtained in sections incubated by displacing drugs.

Areas 18 and 19 showed more uniform binding than area 17, with a gradual dccrcase in labcling from laycr I through VI (Figs. $4 F, 6 C)$. For comparison, the specific binding profile for the tritiated binding antagonist, ${ }^{3} \mathrm{H}$-dihydroalprenolol (Palacios and Kuhar, 1980) was obtained and found to be similar to the ${ }^{125} \mathrm{I}-$ iodopindolol binding profile except that binding of ${ }^{3} \mathrm{H}$-dihydroalprenolol was significantly above background in the white matter of the occipital lobe. Since significant white matter binding was not seen with the ${ }^{125}$ I-iodopindolol, binding to white matter appears to be a property of the dihydroalprenolol compound and not of $\beta$-adrenergic sites in general.

\section{${ }^{3} \mathrm{H}$-quinuclidinyl benzilate $(Q N B)$}

Muscarinic cholinergic receptors were labeled by the ligand ${ }^{3} \mathrm{H}-$ quinuclidinyl benzilate ( $\left.{ }^{3} \mathrm{H}-\mathrm{QNB}\right)$ as employed previously in other mammalian species (Wamsley et al., 1980). While this ligand does not distinguish between the postulated muscarinic agonist subtypes (Birdsall et al., 1978), it does provide an antagonist ligand that would be expected to label all sites with the same high affinity (Wamsley et al., 1980). The potency of this antagonist at cerebral binding sites has a remarkable signal-tonoise ratio (Wamsley et al., 1981) and a short film exposure time, which allowed us to use it both to quantify muscarinic sites and to assess tissue and binding site preservation in each individual case before processing for additional ligands.

Quantitative analysis of autoradiograms reveals that QNB binds considerably more intensely than the adrenergic ligands (Fig. 4G). Furthermore, the distinction between layers appears more pronounced with QNB in both cytoarchitectonic fields (Fig. 6, D, E). In area 17, layers I, IVC-alpha, and VI are the least radioactive, while layers II-III stand out as the most intensely labeled (Figs. $4 G, 6 D$ ). Intermediate levels of radioactivity were present over layers IVA, IVC-beta, and V. The main difference between areas 17 and 18 was that in the former, there were basically only 2 bands, one dark band in the supragranular layers with a peak intensity in II ( $300 \mathrm{fmol} / \mathrm{mg}$ tissue) and another lighter one ( $250 \mathrm{fmol} / \mathrm{mg}$ tissue) in the infragranular layers (Figs. $4 G, 6 E$ ). The subgranular dark band stopped at the $17 / 18$ border, although the transition was more gradual than observed in most other ligands (Figs. $4 H, 6 E$ ). Area 18 had only one dark band ( $300 \mathrm{fmol} / \mathrm{mg}$ tissue) in layer II. The dark band gradually decreased toward VI (Figs. $4 H, 6 E$ ). Both striate and extrastriate visual areas were uniformly labeled throughout, and the intensity of labeled cortex stood in contrast to the absence of any significant binding in the subcortical white matter $(<30 \mathrm{fmol} /$ mg tissue). 

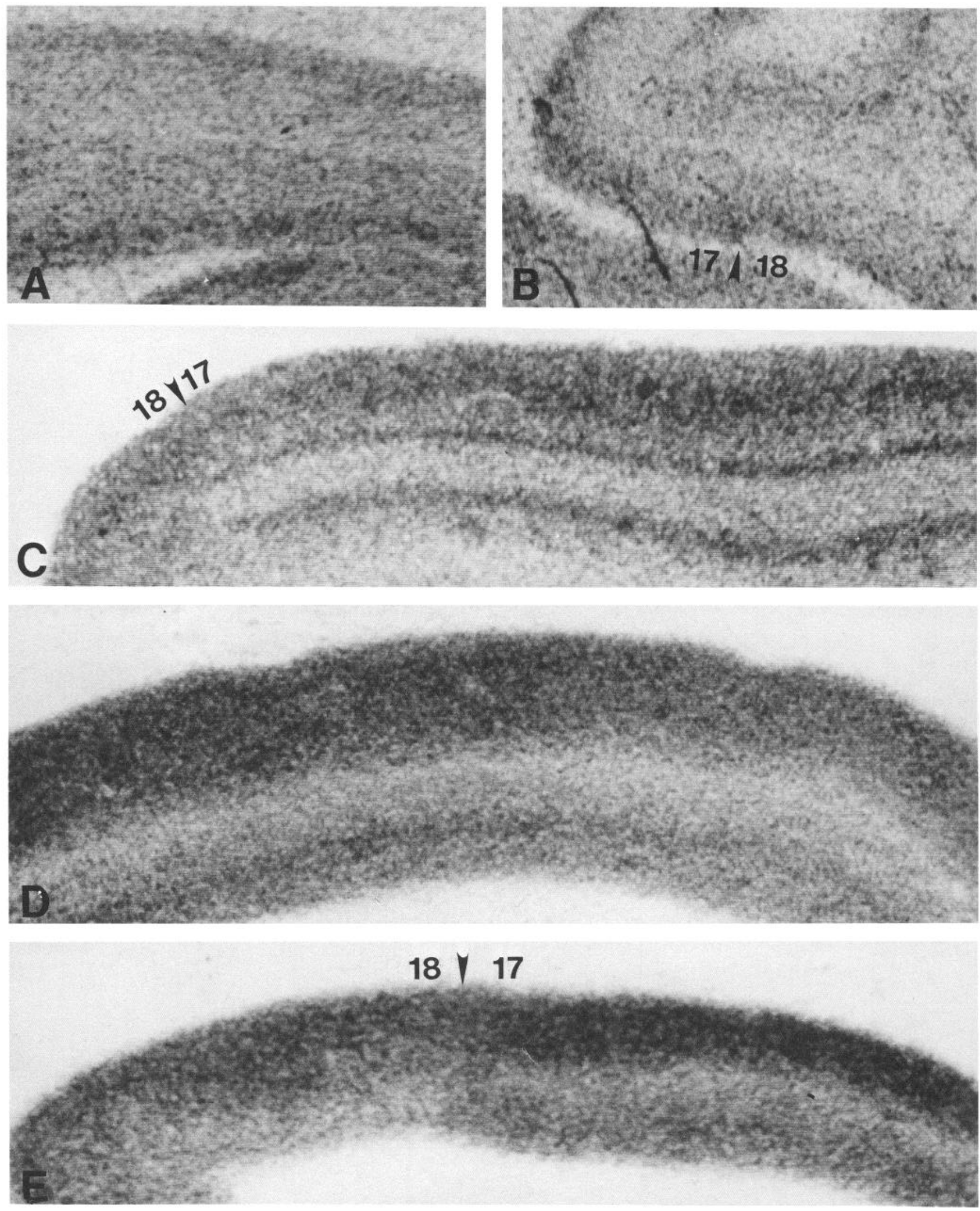

Figure 6. Video images of autoradiograms show the distribution of total radiolabeling following incubation with ligands used to map $\alpha_{1}$ and $\beta$-adrenergic $(A-C)$ and cholinergic $(D-E)$ receptors. $A$, Distribution of ${ }^{3} \mathrm{H}$-prazosin in area 17 of the calcarine fissure. $B,{ }^{3} \mathrm{H}$-prazosin at the $17 / 18$ border. $C,{ }^{125} \mathrm{I}$-Iodopindolol at the $17 / 18$ border. $D,{ }^{3} \mathrm{H}$-quinuclidinyl benzilate at the $17 / 18$ border. Further details are in the text. 


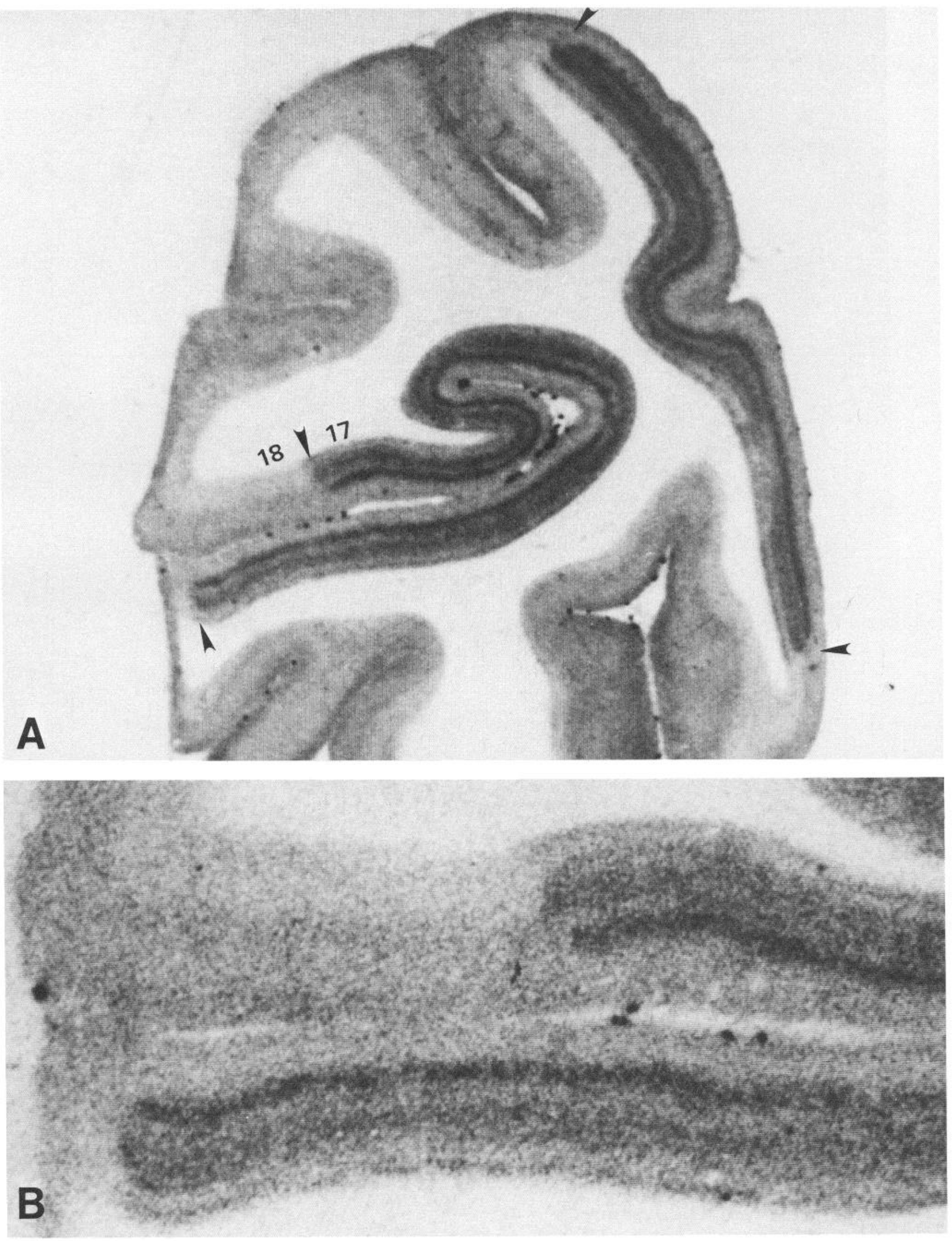

Figure 7. A, Low-power video image of ${ }^{3} \mathrm{H}-5-\mathrm{HT}$ binding sites showing the sharp change in distribution of radioactivity at the borderline between areas 17 and 18 (arrowheads) in the adult rhesus monkey. In vitro binding of this radioligand provides a reliable means of identifying the size of cytoarchitectonic fields and location of their borders. $B$, Higher-power autoradiogram of the $17 / 18$ border and lamination pattern within the calcarine fissure. 


\section{${ }^{3} H$-5-hydroxytryptamine (serotonin)}

Heterogeneity of the serotonin $(5-\mathrm{HT})$ recognition sites in the brain has been demonstrated by a number of biochemical (Peroutka and Snyder, 1979) and functional studies (Rogawski and Aghajanian, 1980; Aghajanian, 1981; Glennon et al., 1984; Lucki et al., 1984). These receptor sites have been classified as $5-\mathrm{HT}_{1}$, labeled by tritiated 5-HT with high (nanomolar) affinity, and $5-\mathrm{HT}_{2}$, recognized by high-affinity binding of spiperone (Peroutka and Snyder, 1979). In the present study, we used highaffinity ${ }^{3} \mathrm{H}-5-\mathrm{HT}$ binding to determine the laminar distribution and quantification of 5-HT sites within striate and extrastriate areas of the primate visual cortex. Recent pharmacological studies of heterogeneity within the $5-\mathrm{HT}_{1}$ site have provided evidence of further subtypes: 5- $\mathrm{HT}_{1 \mathrm{a}}, 5-\mathrm{HT}_{1 \mathrm{~b}}$, and 5-HT $\mathrm{H}_{1 \mathrm{c}}$ (Pazos and Palacios, 1985, Pazos et al., 1985). Although an extensive 5-HT, subtype characterization was not carried out in the present study in primates, we did examine the ability of the $5-\mathrm{HT}_{1 \mathrm{a}}$-selective agonist 8-hydroxy-2-(di-n-propylamino) tetralin (80HDPAT, $10 \mathrm{nM}$ ) to displace ${ }^{3} \mathrm{H}-5-\mathrm{HT}$ binding in both areas of the visual cortex. Our data suggest that there was displacement of ${ }^{3} \mathrm{H}-5-\mathrm{HT}$ binding representing $89-93 \%$ of total binding, suggesting that most of the 5-HT, sites were of the $5-\mathrm{HT}_{1 \mathrm{a}}$ subtype. No difference in the percentage of displacement by $80 \mathrm{HDPAT}$ was observed between striate and extrastriate areas, nor across various laminae.

The binding of ${ }^{3} \mathrm{H}-5-\mathrm{HT}$ in the striate areas was among the most distinctly intensive and reliable of all ligands examined and shows a simple well-defined layering pattern (Fig. 7 and $B_{\max }$ histograms in Fig. 5A). After about 2 months exposure time for the Ultrofilm, 3 distinct slender dark bands could be seen in layers IVA, IVC-beta, and VI, with layer IVC-beta standing out as the most intenscly radioactive (Figs. $1 B, 7 B$ ). The remaining cortical layers were more lightly labeled, producing a highly contrasting image in the autoradingrams (Fig. 7). This profile was largely confirmed by quantitative analysis (Fig. $5 \mathrm{~A}$ ). Although significant IVB binding was seen, white matter attenuation prevented this sublayer from appearing heavily labeled. The trilaminar pattern of 5-HT binding changed abruptly at the border of areas 17 and 18 (Fig. $7, A, B$ ). Because of the large and sudden drop in intense labeling, the border between the 2 areas could easily be recognized at low magnification or even when inspected by the naked eye (Fig. $7 A$ ). Area 18 was more uniformly and lightly labeled than area 17 (Fig. 5B). Radioactivity in the white matter in both areas was at background level. Low radioactivity in the white matter was not due simply to the higher absorption of beta emissions by the myelinated fibers in the subcortical white matter (Unnerstall et al., 1984b), since the 2-month-old infant, containing lesser amounts of myclin, showed an equally low density of grains in the territories below the cortical plate $(40 \mathrm{fmol} / \mathrm{mg}$ tissue in both adult and infant).

\section{${ }^{3} H$-ketanserin $\left(5-H T_{2}\right)$}

Among several candidates for mapping 5-HT receptors (Pazos et al., 1985), ${ }^{3} \mathrm{H}$-ketanserin has been shown to bind with high affinity to $5-\mathrm{HT}_{2}$ sites in the brain (Leysen et al., 1982) with little affinity for dopamine sites (Peroutka and Snyder, 1981). Spiperone was not used because it also has considerable affinity for dopamine sites (Howlett et al., 1979; Palacios et al., 1981a). $5-\mathrm{HT}_{2}$ receptors were identified using the specific $5-\mathrm{HT}_{2}$ antagonist, ${ }^{3} \mathrm{H}$-ketanserin (Leysen et al., 1982). However, as previously mentioned, we incorporated cold prazosin in the binding assay to protect against $\alpha_{1}$-adrenergic binding. In addition, our use of methysergide as the blanking agent assured that $\alpha_{1}$ or histamine binding was not included in specific binding to $5-\mathrm{HT}_{2}$ sites (Leysen et al., 1982).

Although ${ }^{3} \mathrm{H}$-ketanserin is used to assess only a portion of the 5-HT receptor sites, it nevertheless takes $25 \%$ less exposure time for the Ultrofilm to reach the same level of radioactivity as ${ }^{3} \mathrm{H}$ 5-HT. The binding pattern of ketanserin in area 17 was similar to that of 5-HT (compare Figs. 7 and 8). However, careful examination shows only 2 sharply defined dark bands: one in lower layers III and IVA and the other in IVC-beta. The dark band of label that was present over layer VI in 5-HT autoradiograms was not pronounced in ketanserin-labeled sections (Fig. 5C,D). An intermediate level of binding was present in layers I, II, III, IVC-alpha, V, and VI. Layer IVB appeared lightly radioactive, but correction for tritium attenuation indicated that the binding was comparable to adjacent IV sublayers (Fig. 8A). This intricate binding pattern stopped abruptly at the border of area 17 (Fig. $8 B$ ). The $17 / 18$ border was sharp because area 18 had a darker band in the middle of the cortex (layer III), a less intense band in layer IV, and an intermediate level of radioactivity without any distinct layering pattern in the rest of the cortex (Figs. $5, C, D ; 8$ ).

\section{${ }^{3} \mathrm{H}$-flunitrazepam (Flu)}

This ligand was used for assessing low-affinity GABA and benzodiazepine receptors. Since recent immunoprecipitation studies of Mohler and coworkers (Haring et al., 1985) indicate that binding sites for benzodiazepines as well as high- and low-affinity GABA sites reside on the same structural complex, it was reasonable to assume that ${ }^{3} \mathrm{H}-\mathrm{Flu}$ and ${ }^{3} \mathrm{H}$-muscimol (described below) sites should colocalize. However, there is a mismatch of these 2 ligands in the rodent cerebellum (Young and Kuhar, $1980 \mathrm{c})$. In addition, ${ }^{3} \mathrm{H}$-muscimol fails to label deep cerebellar nuclei of the rhesus monkey despite anatomical, physiological, and biochemical evidence of GABAergic innervation (Herkenham, 1985). On the other hand, ${ }^{3} \mathrm{H}$-Flu binding can be demonstrated in these nuclei, consistent with the presence of the $\mathrm{GABA} /$ benzodiazepine complex in this region.

In our hands, ${ }^{3} \mathrm{H}$-Flu had a distinct bilaminar pattern throughout the entire area 17 (Fig. 9A). Careful quantitative analysis revealed 2 intense bands running within layer IVC and only the upper strata of layer VI (Fig. $5 E$ ). This was, therefore, a good example of binding that was not confined to an entire layer, but rather to only a portion of it, indicating that biochemical specificity exists even in morphologically uniform layers. An intermediate level of binding was present in layers I, II, III, and the upper moiety of VI, and only light radioactivity could be seen in layers IVB and V. Again, the apparent low binding in layer IVB is compensated by tissue quenching. After correction, the density in this layer was comparable to other sublayers (Fig. $5 E$ ). This pattern also changed abruptly at the $17 / 18$ border (Fig. 9B). Although area 18 was also bilaminar, the distribution and intensity were different (Fig. $5 F$ ). In the latter field, there was one broad band situated over layers II and III, and the other was situated at the border of layers IV and V (the lower stratum of layer IV and the upper stratum of layer V), again exposing a sublaminar pattern. The remainder of the cortex was lightly and rather uniformly labeled. The white matter was devoid of significant amounts of specific binding (Fig. 9, $A, B$ ). $B_{\max }$ values corresponding to these binding profiles are shown in Figure 5 , $E, F$. 

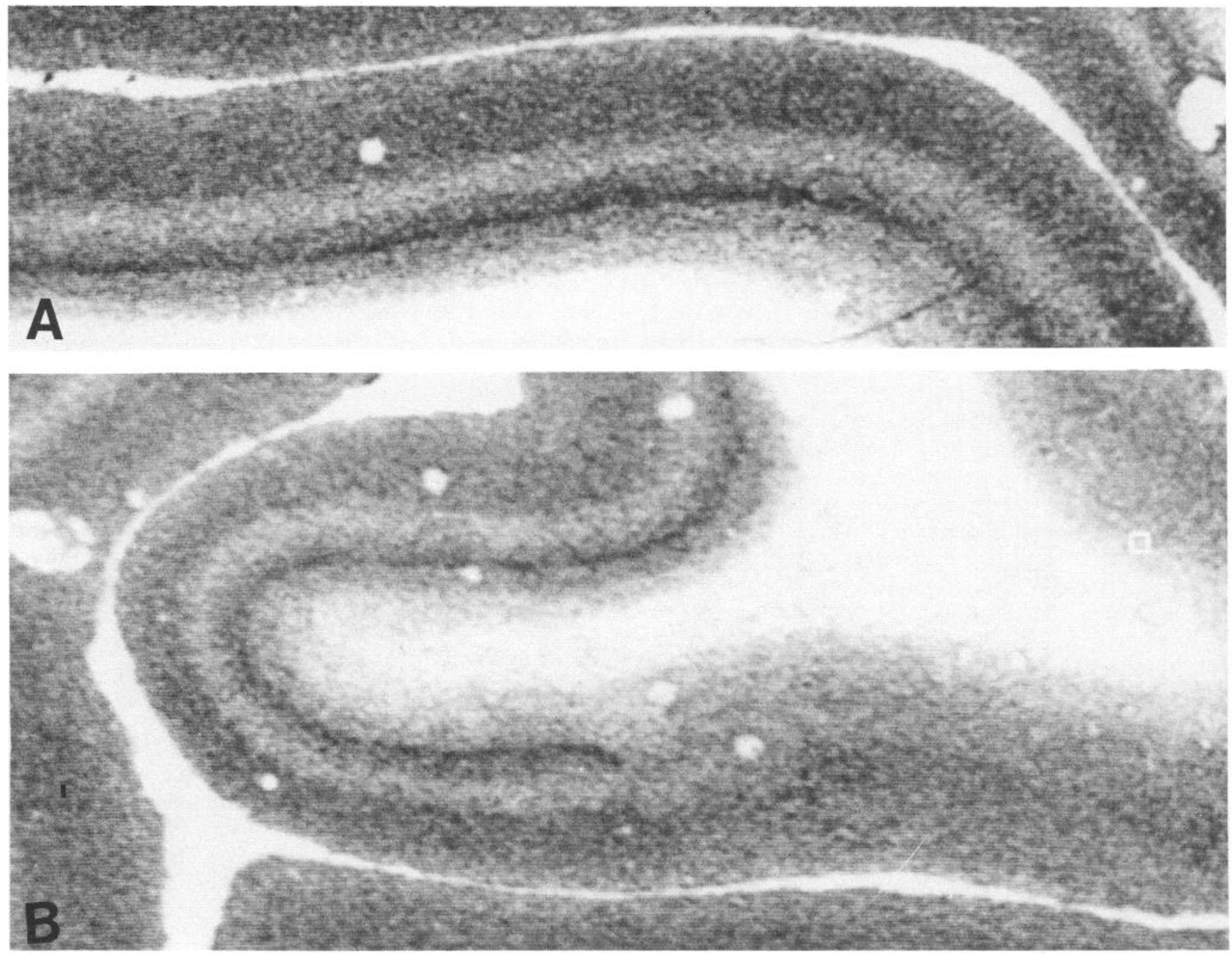

Figure 8. Video image display of the laminar and areal distribution of ${ }^{3} \mathrm{H}$-ketanserin labeling in area $17(A)$ and at the $17 / 18$ border $(B)$ of the occipital lobe.

\section{${ }^{3} \mathrm{H}$-muscimol}

Since the low-affinity GABA site appears to interact with benzodiazepines and mediates physiological responses to GABA (Olsen et al., 1984; Tallman and Gallager, 1985), ${ }^{3} \mathrm{H}$-muscimol binding was measured primarily to determine if areas unrecognized by the benzodiazepine ligand could be detected by ${ }^{3} \mathrm{H}-$ muscimol. Autoradiograms of the slides incubated with this ligand displayed a dark band over layer IVC that stood out rather sharply as a thin, dark line interposed between lighter labeled sublayers IVA and IVB above and layers IVC-beta, V and VI below (Fig. 9C). Supragranular layers II and III were moderately labeled except for the lower stratum in layer IVA and layer I, which were even more lightly labeled. At the border between areas 17 and 18, the dark IVC band totally disappeared and the light density of layers I and IVA blended with the surrounding layers. As a result, area 18 had an essentially bilaminar pattern: the superficial-most layers (I-III) were represented by a single uniform band of moderate intensity, which merged gradually with the lighter radioactivity of layers IV-VI. Radioactivity of the white matter was low, even after correction for quenching. Under the incubation conditions utilized here, ${ }^{3} \mathrm{H}$-muscimol apparently binds with multiple affinities; thus, no reliable $B_{\max }$ could be obtained over the concentration range examined. However, the binding profile at a single concentration reflects high-affinity binding as shown in Figure $5, G, H$.

\section{${ }^{3} \mathrm{H}$-spiperone}

Radiolabeled spiperone has been utilized in a number of dopamine receptor binding studies because of its high affinity for dopamine binding sites and low levels of nonspecific binding (Leysen et al., 1978). Although there is evidence for binding to other neurotransmitter binding sites (Peroutka and Snyder, 1979), the use of specific pharmacological agents to displace various sites has been successfully employed to obtain dopamine-specific binding (Palacios et al., 1981a). In our study, binding was carried out in the presence of ketanserin to block $5-\mathrm{HT}_{2}$ binding; dopamine-specific binding was that binding remaining after $(+)$ butaclamol. In area $17,{ }^{3} \mathrm{H}$-spiperone binds most highly to layer IVC-beta; moderately to layers I, II, III, IVA, IVC-alpha, and V; and least to layers IVB and VI (Fig. 9D). No significant binding to white matter was observed, even after correction for quenching. This layering pattern, confirmed by quantitative analysis (Fig. $5 E$ ), disappeared at the $17 / 18$ border. Examination of density indicates that area 18 does not display any marked 

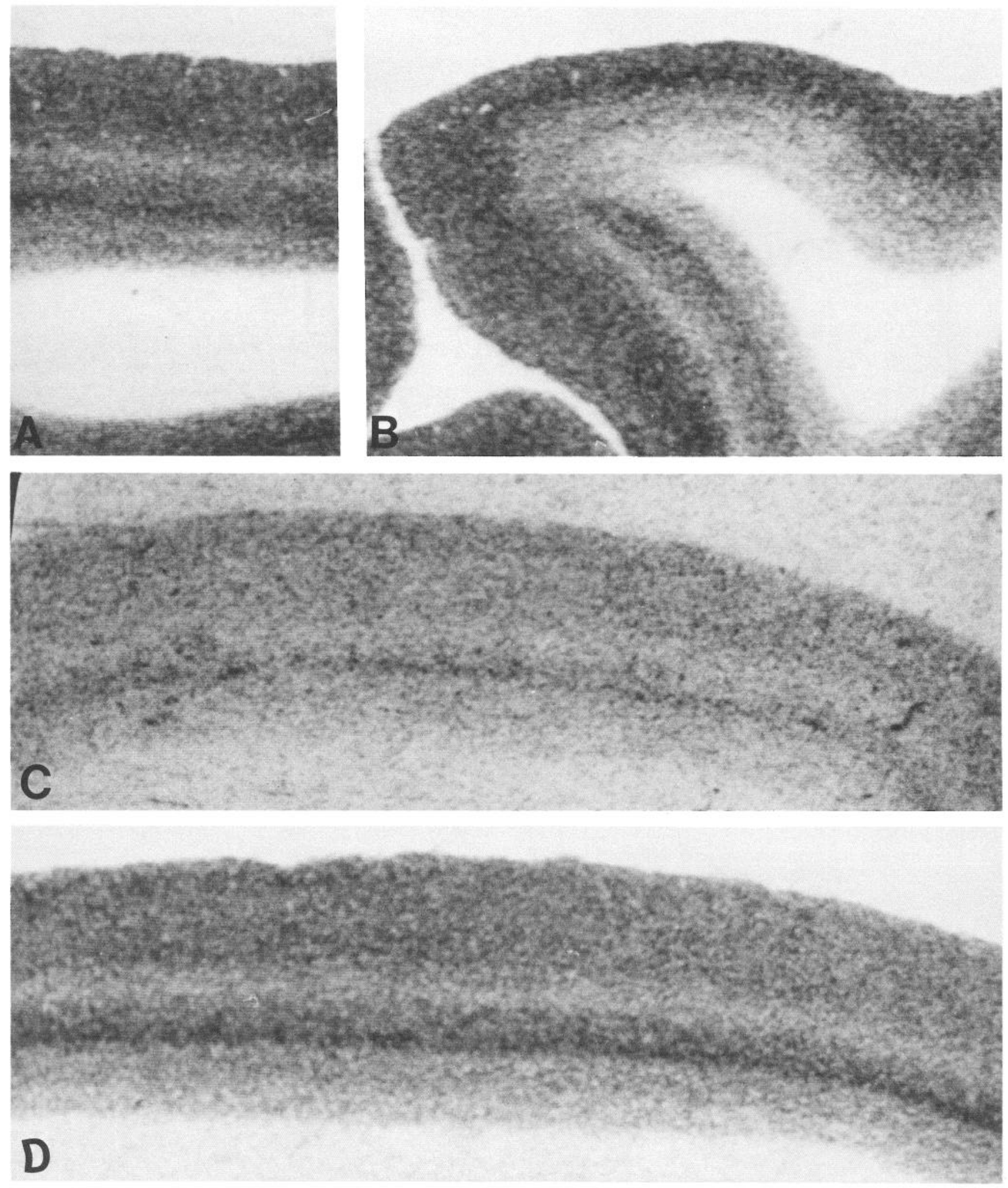

Figure 9. Video image of the areal and laminar distribution of ${ }^{3} \mathrm{H}$-flunitrazepam in area $17(A)$ and at the $17 / 18$ border $(B) ;{ }^{3} \mathrm{H}$-muscimol $(C)$ and ${ }^{3} \mathrm{H}$-spiperone $(D)$ in area 17 of the visual cortex of the adult rhesus monkey (see text).

lamination; rather, it appeared to have maximal binding in the middle layers and to decrease in a continous gradient above and below these layers without evidence of a strong preference for any layer or sublayer (Fig. $5, I, J)$. The apparent affinities $\left(K_{d}\right)$ were most variable for this ligand (example: $K_{d}=1.1$ for layer IVB, $K_{d}=4.2$ for layer VI). However, such changes could not be systematically correlated with $B_{\max }$ differences between layers and may represent inherent variability for this ligand binding 
assay. Variation in apparent affinity for ${ }^{3} \mathrm{H}$-spiperone has been previously reported in the rodent (Altar et al., 1985).

\section{Discussion}

\section{Laminar and areal specificity}

Even cursory examination of the pattern of binding of the 9 ligands used in this study demonstrates remarkable differential distribution in the primate cortex. The differences in distribution and intensity are so distinct and reliable from animal to animal that the chemoarchitecture of the neocortex, at least for primary versus secondary visual areas, may rival the discrimination of cortical areas by the classical cyto- and myeloarchitectural methods studied extensively at the turn of the century. Some ligands have a preferential affinity for the cell-rich layers; others are more concentrated over strata abundant in fibers (neuropil), but none are exclusively present in one or another cytological compartment in the same or both cortical areas examined. For example, in area 17, spiperone binding is among the densest in layer I, which is cell-poor, and low in layer VI, which is cell-rich (Figs. 10 and 11). In contrast, in area 18 it displayed low affinity for cell-poor layer I and high affinity for cell-rich layer III (Fig. 5, $I, J$. Likewise, within the cell-rich layers, the intensity of binding does not correspond to relative cell densities. QNB, for example, is equally distributed in layers $\mathrm{V}$ and IVC-beta of area 17, although they have unequal cell density. In contrast, this same ligand is differentially distributed over layers II and III of the area 18, which have similar cell density and fiber content.

Correspondence and noncorrespondence in the distribution of various ligands within the 2 cytoarchitectonic areas also offer insight into the relationship to the cellular organization of these areas. Our results reveal that 2 ligands may be overlapping in one area and differentially distributed in the other. For example $\alpha_{1}$ - and $\beta$-adrenergic receptors are distributed over identical layers in area 18 (Fig. $11, C, D$ ), while they occupy different layers in area 17 (Fig. 10,C,D). This finding indicates that the 2 subtypes of adrenergic receptor are contained in different cellular compartments that share common territories in area 18 but are distributed in different territories within area 17 . Thus, correspondence of 2 ligands in one area does not necessarily indicate their presence on the same cellular elements.

Distribution of some ligands allows further dissection of cytoarchitectonically uniform layers into biochemically distinct sublayers. For example, Flu subdivides layer VI into 2 horizontal zones that are not discernible in Nissl-stained sections but contains neurons that project to 2 different synaptic targets as shown by retrograde transport of HRP (Lund et al., 1975). Some ligands clearly display a distinct and intricate horizontal pattern of distribution with a sharp transition between layers, while others have a broader and more uniform distribution, showing only a slight, graded distribution in certain layers. Thus, analysis of receptor lamination reveals molecular heterogeneity that cannot be detected by classical cytoarchitectonic criteria.

Finally, within a given cytoarchitectonic area all receptors seemed to be distributed uniformly across the tangential plane of the cortex. We could not discern any alternating patches of higher and lower densities that would reflect foci of high concentrations of GAD-positive terminals (Hendrickson et al., 1981) or periodicity of corticocortical connections between areas 17 and 18 (Rockland and Pandya, 1981; Livingstone and Hubel, 1984).

These findings collectively indicate that the distribution of ligands must correlate with some cellular properties other than a simple division of the cortex into cell- and neuropil-rich compartments, and the recorded differences cannot depend on differential absorptions of beta particles among these 2 principle cellular compartments. Rather, our findings indicate that binding of ligands differentiates between various areas, probably on the basis of their connectivity (see below). Similar, although perhaps less dramatic, differences in ligand binding can be expected for other cytoarchitectonic areas of the cortex. Indeed, areal specificity has already been found in the distribution of specific serotonergic agonists in the primate frontal lobe (Goldman-Rakic et al., 1987).

\section{Correspondence with pattern of connectivity}

It is of considerable theoretical and practical interest to relate neurotransmitter laminar distribution to the termination of various afferent systems and/or to the distribution of neural classes that project to specific targets within or outside the cortex. Although this approach appears to be obvious and highly promising, it is constrained by the presence of multiple and often overlapping inputs from various sources to the same layers Further, as evident from our study, receptors can be localized at present only to a given cortical layer and occasionally to its sublayer. Since most neurons extend their dendrites and axons beyond the boundaries of a given layer, it is not possible to pinpoint neuronal types involved in transmitter receptor interaction. Additionally, because of our still incomplete knowledge of the exact site of termination of afferents and, in particular, of their relative proportion in a single layer, correlation with specific afferent systems, even for well-established receptors, provides only interesting hints but no definitive conclusions. Finally, our ignorance of the preferential distribution of these receptors in the pre- or postsynaptic elements makes any conclusion about their cellular localization rather illusive. Nevertheless, although perfect transmitter-receptor matches are not, at present, possible, the findings of their correspondence or noncorrespondence provide useful leads for future functional and anatomical analyses.

The most intensively labeled bands of ${ }^{3} \mathrm{H}$-clonidine in area 17 (Fig. $11 E$ ) correspond best to the termination of input from the parvocellular layers of the lateral geniculate nucleus in layers IVA, IVC-beta, and the upper moiety of VI $\left(\mathrm{A}_{1}\right.$ in Fig. 11D). Layer IVC-alpha and the lower moiety of layer III, which receive input from the magnocellular layers of the lateral geniculate nucleus $\left(\mathrm{A}_{2}\right.$ in Fig. $\left.11 D\right)$ have a moderate but regularly lower intensity of binding. These 2 classes of thalamic inputs, both originating from the lateral geniculate nucleus, are known to have different physiological properties (Hubel and Wiesel, 1977) and have different biochemical compositions, as shown by the distribution of cell class-specific antigens (Hendry et al., 1984). The preferential binding of the $\alpha_{2}$-adrenergic receptor by ${ }^{3} \mathrm{H}$ clonidine in the layers that receive predominately thalamic input is further substantiated by the distribution of this ligand in the adjacent extrastriate visual cortex. In area 18 , clonidine has a substantially different distribution, but, again, its localization coincides remarkably well with input from the pulvinar, which projects predominantly to layers I and III. In this respect, the distribution of clonidine in areas 17 and 18 is very similar to that of the cholecystokinin (CCK) receptor that has also been localized to thalamocortical targets in areas 17 and 18 , as well as in other cortical areas (Kritzer et al., 1987). Receptors for another monoamine, 5-HT, also seem to be localized to major 


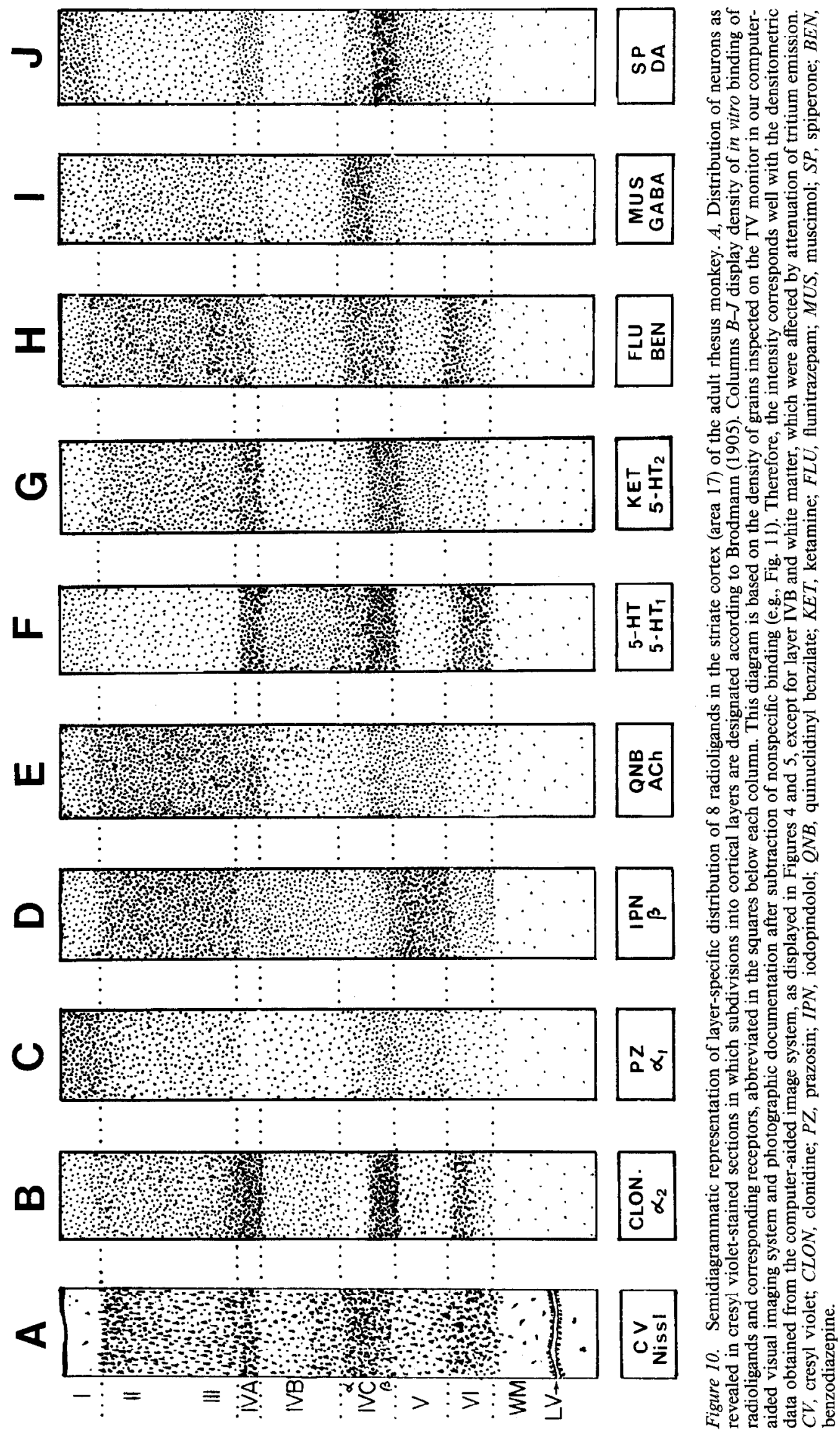




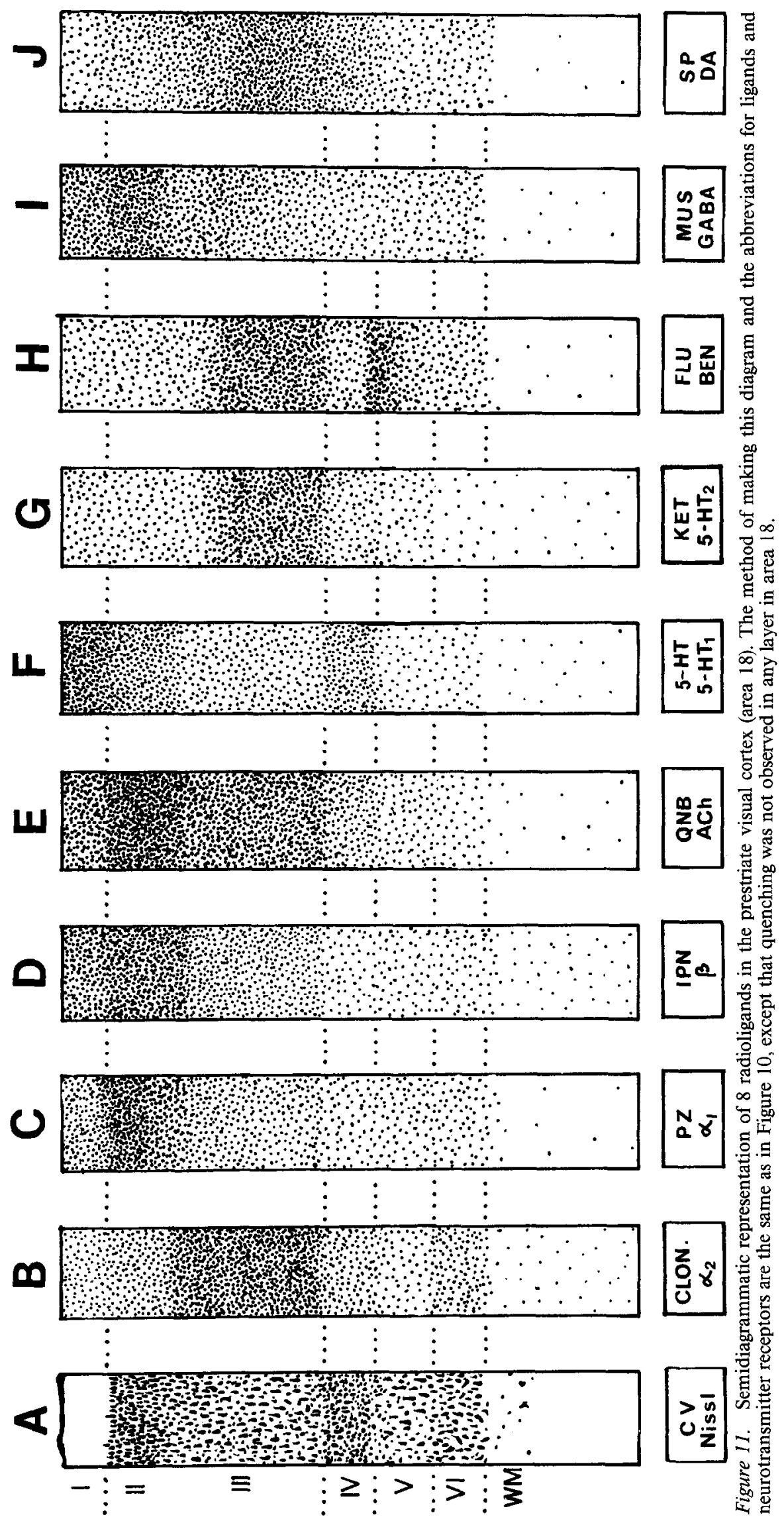




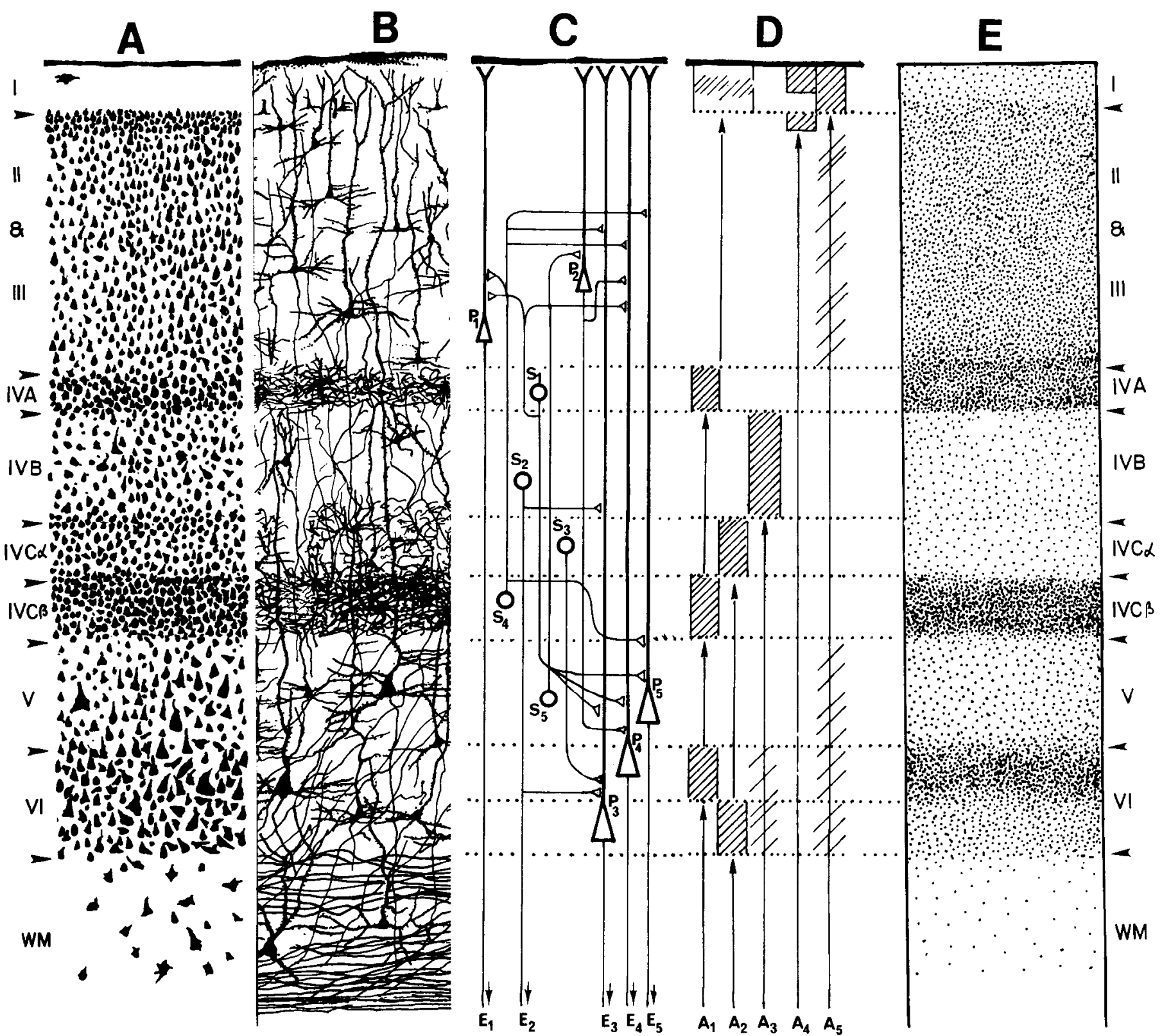

Figure 12. Composite diagram of the laminar organization of the primary visual cortex of the rhesus monkey integrating observations derived by several techniques (modified from Rakic and Goldman-Rakic, 1982). $A$, Cytoarchitectonic appearance of the primary visual cortex (area 17) in Nissl stain displays horizontal cell stratification into layers and sublayers. $B$, Appearance of visual cortex neurons in Golgi impregnations and afferent axonal plexules in sublayers stained by the reduced silver method. $C$, Simplified diagram of the origin and termination of major neuronal circuits within the cortex. It is evident that stellate cells of sublayers IVC-beta $\left(\mathbf{S}_{4}\right)$ and IVA $\left(\mathbf{S}_{1}\right)$ project predominantly to layer III, where they synapse either directly upon dendrites of efferent pyramidal cells $\left(\mathbf{P}_{1}\right.$ and $\left.\mathbf{P}_{2,2,4}\right)$ or indirectly through another local circuit neuron (small pyramidal cell $P_{2}$ ). The majority of stellate cells of sublayer IVC-alpha (e.g., $\left.S_{3}\right)$ probaby contact efferent pyramids $\left(P_{3}\right)$ within layer V. Some stellate cells of layer IV-beta $\left(\mathrm{S}_{2}\right)$ contact nearby neurons within the same layer but also project to adjacent visual association cortex $\left(\mathrm{E}_{2}\right)$. However, most visual efferents are formed by large pyramids $\left(\mathrm{P}_{3-5}\right)$ of layer $\mathrm{V}$, which project to the superior colliculus $\left(\mathrm{E}_{3}\right)$; pyramids of upper layers VI $\left(\mathrm{P}_{4}\right)$, which project to the parvocellular moiety of the lateral geniculate nucleus $\left(\mathrm{E}_{4}\right)$; and pyramids of lower VI $\left(\mathrm{P}_{5}\right)$, which project to the magnocellular moiety $\left(\mathrm{E}_{5}\right)$. $D$, Relative position of the terminal field originating from 5 major afferent systems: $A_{1}$ (from the parvocellular moiety of LGd), $A_{2}$ (from the magnocellular moiety of LGd), $\mathrm{A}_{3}$ (from the superior temporal cortex), $\mathrm{A}_{4}$ (from the inferior pulvinar), and $\mathrm{A}_{5}$ (from area 18 ). $E$, Distribution of the $\alpha_{2}$-adrenergic receptor as exposed by ${ }^{3} \mathrm{H}$-clonidine binding in area 17 .

terminal targets of axons originating in the LGd (compare Fig. $10 F$ with $\mathrm{A}_{1}$ in Fig. $12 \mathrm{D}$ ). Thalamic input to layer IV in the monkey is mostly excitatory (Mitzdorf and Singer, 1979), and localization of these 2 monoamine receptors seems to be strategically placed.

Detailed examination of the autoradiograms indicates that, although some ligands can be correlated with the presently known subcortical inputs to a given cortical area, other ligands (notably QNB and muscimol in both areas 17 and 18) are distributed preferentially in layers that are known to have a high concentration of neurons that issue corticocortical and corticosubcortical projections (Fig. 12, C,D). Thus, QNB has a high density in layers III and $\mathrm{V}$, which contain mostly neurons projecting to other cytoarchitectonic areas and to the superior colliculus (Fig. 
$4, G, H)$. On the other hand, GABA receptors in both visual areas are predominantly concentrated in layers II and III (Fig. $5, G, H)$ that are thought to be major sites of inhibitory action. In addition, there is a distinct dark QNB band in layer IVCalpha in area 17 that needs physiological explanation.

Although individual ligands in one or the other cortical area may be correlated with a particular layer-specific input or output, such correlations do not hold for all ligands in both areas. Possibly the lack of correspondence reflects our still imperfect knowledge about neural circuitry between and among visual areas. However, the highly specific laminar distribution of receptors, which is independent of cell or fiber density, provides a basis for expecting tighter relationships between the pattern of binding and the pattern of connectivity to become apparent with further analysis of the synaptic architecture of the visual regions.

\section{"Mismatch" of receptors and neurotransmitters}

Recently, considerable attention has been given to the "mismatch" between levels of neurotransmitters and the density of relevant receptors in various nuclei and areas of the brain (Kuhar et al., 1986; Herkenham, 1987). The general agreement is that in the CNS, the precise "matches" between transmitters and their putative receptors are the exception rather than the rule. Striking examples of both correspondence and mismatch were uncovered in the present study. The distribution of ${ }^{3} \mathrm{H}-5-\mathrm{HT}$ in our study corresponds rather well with the distribution of 5-HT defined by immunoreactivity (Morrison et al., 1982; Morrison and Foote, 1986). In harmony with the present study, 5-HT immunoreactivity is high in layer IV in area 17, while lower and more diffuse across all layers in area 18. The implication of these findings is that brain-stem monoamine pathways may converge with the thalamocortical innervation. Distribution of the $\alpha_{1}$-adrenergic receptor in areas 17 and 18 , as determined by the distribution of prazosin, also seems to correlate, though less perfectly, with inputs from the lateral pulvinar of the posterior thalamus (compare Fig. $10 C$ and input $A_{4}$ and $A_{5}$ in Fig. 12D).

An example of mismatch was revealed by our analysis of the $\alpha_{2}$-adrenergic receptor, clonidine, which is present in moderate density in layer IVC-beta of area 17 in the rhesus monkey. Immunohistochemical studies of noradrenergic-containing axons in visual cortex of another macaque species, Macaca fascicularis, reveal a virtual absence of such fibers in the entirety of layer IV (Morrison and Foote, 1986). If the binding sites indeed signal the receptors where adrenergic transmitters act, perhaps the apparent "mismatch" exposes a limitation of the immunocytochemical methods used to label the terminal arborizations of monoaminergic fiber systems. On the other hand, the density of receptors in layer IVC-beta may be required to compensate for low levels of transmitter available in this territory for its activation (Foote and Morrison, 1987; Herkenham 1987). In support of this idea, ${ }^{3} \mathrm{H}$-citalopram binding in area 17 is particularly high in layers IVB and IVC-alpha where 5- $\mathrm{HT}_{1}$ and $5-\mathrm{HT}_{2}$ binding sites are relatively low (Goldman-Rakic et al., 1987). In any event, quantitative receptor autoradiography can complement immunohistochemistry in deciphering the localization of cortical neurotransmitters. For example, immunohistochemical studies show, respectively, low and high densities of norepinephrine and 5-HT fibers in layer IV of primary visual cortex. However, our data show that norepinephrine, 5-HT, and dopamine receptors are all present in layer IVC-beta of area 17, although in different concentrations. Presumably, then, in the striate cortex, layer IV is a target of both norepinephrine and 5-HT and not a selective target of 5-HT-containing axons.

\section{Species-specific differences}

Various cytoarchitectonic properties of the visual cortex are more differentiated in primate than in nonprimate species, and it is reasonable to expect, as evidence in humans already indicates, that the binding of ligands would reflect some of these differences (Palacios et al., 1986). The most obvious cytoarchitectonic difference relevant to the present study is the sharpness of the border between areas 17 and 18, and the complexity of cortical lamination. Another less emphasized difference between the visual cortices of primate and nonprimate species is the distribution of neurotransmitter receptors within the layers that receive input from the magnocellular and parvocellular moieties of the lateral geniculate nucleus. These 2 moieties of the lateral geniculate nucleus reflect the segregation of $\mathrm{X}$ - and $\mathrm{Y}$-like neurons that are not separated in nonprimate mammalian species examined so far. They are, however, distinct in macaque monkeys, and they terminate in the well-delineated, separate strata of layer IV (Hubel and Wiesel, 1977). In the present study, the GABAergic ligand, muscimol, showed a clear distinction in binding intensity between the sublayers, layers IVC-alpha and IVC-beta, that receive differential input from the $\mathrm{Y}$ - and $\mathrm{X}$-like geniculate neurons, respectively (Fig. 9). In contrast, in mammals in which these 2 classes of cells and terminals are not separated, muscimol binding in the lateral geniculate nucleus exhibits no such difference in distribution and intensity (Needler et al., 1984; Wamsley, 1985).

The similarity in receptor binding among closely related primate species is remarkable, though even here some speciesspecific differences have been observed. For cxamplc, the distribution of 2 of the 3 ligands (QNB, muscimol) that were examined in cynomolgus monkeys by Shaw and Cynader (1986) was qualitatively similar to that in the present study (Shaw and Cynader did not provide quantitative data).On the other hand, the binding of Flu in our material obtained from rhesus monkeys displayed an additional, distinct dark band in the upper stratum of layer VI that was not observed in cynomolgus monkeys, raising the possibility that there may be a difference in distribution of this ligand within the primate order. These findings indicate that in vitro autoradiographic localization of receptors may prove a useful parameter for the study of cortical homologies. It can be expected that this type of quantitative analysis will provide new insight into cortical mechanisms in primates and their possible role in a number of neurological disorders in man.

\section{References}

Aghajanian, G. K. (1981) The modulatory role of serotonin at multiple receptors in brain. In Serotonin Neurotransmission and Behavior, B. L. Jacobs and A. Gelperin, eds., pp. 156-185, MIT Press, Cambridge, MA.

Altar, C. A., H. Kim, and J. F. Marshal (1985) Computer imaging and analysis of $D_{2}$ and $S_{2}$ sites labeled by ${ }^{3} \mathrm{H}$-spiperone in rat basal ganglia or neocortex. J. Pharmacol. Exp. Ther. 233: 1-11.

Birdsall, N. J. M., A. S. V. Burgen, and E. C. Hulme (1978) The binding of agonists to brain muscarinic receptors. Mol. Pharmacol. 14: 723-736.

Bjorklund, A., I. Divac, and O. Lindvall (1978) Regional distribution of catecholamines in monkey cerebral cortex, evidence for a dopaminergic innervation of the primate prefrontal cortex. Neurosci. Lett. 7: $115-119$ 
Brodmann, K. (1905) Beitrage zur histologischen localization der Grosshirnrinde. Dritte Mitteilung: Die Rinderfelder niederen Affen. J. Phychol. Neurol. (Leipzig) 9: 177-226.

Brown, R. M., A. M. Crane, and P. S. Goldman (1979) Regional distribution of monoamines in the cerebral cortex and subcortical structures of the rhesus monkey: Concentrations and in vivo synthesis rates. Brain Res. 168: 133-150.

Dashwood, M. R. (1983) Central and peripheral prazosin binding: An in vitro autoradiographic study in the rat. Eur. J. Pharmacol. 86: 5158.

Foote, S. L., and J. H. Morrison (1987) Extrathalamic modulation of cortical function. Annu. Rev. Neurosci. 10:67-95.

Gilbert, C. D., and T. N. Wiesel (1981) Laminar specialization and intracortical connections in cat primary visual cortex. In The Organization of the Cerebral Cortex, F. O. Schmitt, ed., pp. 163-191, MIT Press, Cambridge, MA.

Glennon, R. A., M. Titeler, and J. D. McKenney (1984) Evidence for $5-\mathrm{HT}_{2}$ involvement in the mechanism of action of hallucinogenic agents. Life Sci. 35: 2505-2511.

Glossmann, H., F. Lubbecke, and P. Bellemann (1981) ${ }^{125}$ I-HEAT, a selective high affinity, high specific activity ligand for alpha $\mathrm{a}_{1}$-adrenoceptors. Naunyn Schmiedebergs Arch. Pharmacol. 318: 1.

Goldman-Rakic, P. S., M. S. I idow, D. W. Gallager, and P. Rakic (1987) Quantitative autoradiographic mapping of 5- $\mathrm{HT}_{1}, 5-\mathrm{HT}_{2}$ receptors and citalopram in frontal, parietal and occipital cortex of adult rhesus monkeys. Abst. Soc. Neurosci 13: 1237.

Haring, P., C. Stahli, P. Schoch, B. Takacs, T. Staehelin, and H. Mohler (1985) Monoclonal antibodies reveal structural homogeneity of $\gamma$-aminobulyric acid/benzodiazepine receptors in different brain areas. Proc. Natl. Acad. Sci. USA 82: 4837-4841.

Hedreen, J. C., G. R. Uhl, S. J. Bacon, D. M. Fambrough, and D. L. Price (1984) Acetylcholinesterase-immunoreactive axonal network in monkey visual cortex. J. Comp. Neurol. 226: 246-254.

Hendrickson, A. E., S. P. Hunt, and J.-Y. Wu (1981) Immunocytochemical localization of glutamic acid decarboxylase in monkey striate cortex. Nature 292: 605-607.

Hendry, S. H. S., S. Hockfield, E. G. Jones, and R. McKay (1984) Monoclonal antibody that identifies subset of neurones in the central nervous system of monkey and cat. Nature 307: 267-269.

Hendry, S. H. S., H. D. Schwark, E. G. Jones, and J. Yan (1987) Numbers and proportions of GABA-immunoreactive neurons in different areas of monkey cerebral cortex. J. Neurosci. 7: 1503-1519.

Herkenham, M. (1985) Levels of quantitative analysis of receptor autoradiography: Technical and theoretical issues. NIDA Res. Monogr. 62: 13-29.

Herkenham, M. (1987) Mismatches between neurotransmitter and receptor localizations in brain: Observations and implications. Neuroscience 23: 1-38.

Herkenham, M., and L. Sokoloff (1984) Quantitative receptor autoradiography: Tissue defatting eliminates differential self-absorption of tritium radiation in gray and white matter of brain. Brain Res. 321 : 363-368.

Howlett, D. R., H. Morris, and S. R. Nahorski (1979) Anomalous properties of ${ }^{3} \mathrm{H}$-spiperone binding sites in various areas of the rat limbic system. Mol. Pharmacol. 415: 506-514.

Hoyer, D., A. Pazos, A. Probst, and J. M. Palacios (1986a) Serotonin receptors in the human brain. I. Characterization and autoradiographic localization of $5 \mathrm{HT}_{1 \mathrm{~A}}$ recognition sites. Apparent absence of $5 \mathrm{HT}$ recognition sites. Brain Res. 376: 85-96.

Hoyer, D., A. Pazos, A. Probst, and J. M. Palacios (1986b) Serotonin receptors in the human brain. II. Characterization and autoradiographic localization of $5 \mathrm{HT}_{1 \mathrm{C}}$ and $5 \mathrm{HT}_{2}$ recognition sites. Brain Res. 376: 97-107.

Hubel, D. H., and T. N. Wiesel (1977) Functional architecture of macaque monkey visual cortex. Proc. Soc. London [Biol.] 198: 1-59.

Jones, E. G., and A. Peters (1985) Cerebral Cortex, Vol. 2: Functional Properties of Cortical Cells, Plenum, New York.

Jones, L. S., L. L. Gauger, and J. N. Davis (1983) Brain $\alpha_{1}$-adrenergic receptors: Suitability of ${ }^{125}$ I-HEAT as a radioligand for in vitro autoradiography. Eur. J. Pharmacol. 93: 291-292.

Kritzer, M. F., R. B. Innis, and P. S. Goldman-Rakic (1987) Autoradiographic localization of cholecystokinin receptors in primate cortex. J. Comp. Neurol. 263: 418-435.

Kuhar, M. J., and J. R. Unnerstall (1982) In vitro labeling receptor autoradiography: Loss of label during ethanol dehydration and preparative procedures. Brain Res. 244: 178-181.
Kuhar, M. J., E. B. De Souza, and J. R. Unnerstall (1986) Neurotransmitter receptor mapping by autoradiography and other methods. Annu. Rev. Neurosci. 9: 27-59

Lakoski, J. M., and G. K. Aghajanian (1985) Effects of ketanserin on neuronal responses to serotonin in the prefrontal cortex, lateral geniculate and dorsal raphe nucleus. Neuropharmacology 24: 265-273.

Levitt, P., P. Rakic, and P. S. Goldman-Rakic (1984) Region-specific distribution of catecholamine afferents in primate cerebral cortex: A fluorescence analysis. J. Comp. Neurol, 227: 23-36.

Leysen, J. E., W. Gommeren, and P. Laduron (1978) Spiperone: A ligand of choice for neuroleptic receptors. I. Kinetics and characteristics of in vitro binding. Biochem. Pharmacol. 27: 307-316.

Leysen, J. E., C. J. E. Niemegeers, J. M. Van Neuten, and P. M. Laduron (1982) ${ }^{3} \mathrm{H}$-Ketanserin ( $\mathrm{R} 41468$ ), a selective ${ }^{3} \mathrm{H}$ ligand for serotonin ${ }_{2}$ receptor binding sites. Mol. Pharmacol. 21: 301-314.

Lidow, M. S., D. W. Gallager, P. S. Goldman-Rakic, and P. Rakic (1987) Quantitative autoradiography: Comparison of labeling in cerebral cortex of rhesus monkey with $\left[{ }^{3} \mathrm{H}\right]-\left[{ }^{125} \mathrm{I}\right]$ - and $\left[{ }^{14} \mathrm{C}\right]$-compounds. Soc. Neurosci. Abstr. 13: 710 .

Livingstone, M. S., and D. H. Hubel (1984) Anatomy and physiology of a color system in the primate visual cortex. J. Neurosci. $4: 309-$ 356.

Lucki, I., M. S. Nobler, and A. Frazer (1984) Differential actions of serotonin antagonists on two behavioral models of serotonin receptor activation in the rat. J. Pharmacol. Exp. Ther. 228: 133-139.

Lund, J. S. (1981) Intrinsic organization of the primary visual cortex, area 17, as seen in Golgi preparations. In The Organization of the Cerebral Cortex, F. O. Schmitt, ed., pp. 106-124, MIT Press, Cambridge, MA.

Lund, J. S., R. D. Lund, A. E. Hendrickson, A. H. Bunt, and F. Fuchs (1975) The origin of efferent pathways from the primate visual cortex, area 17 , of the macaque monkey as shown by retrograde transport of horseradish peroxidase. J. Comp. Neurol. 164: 287-304.

McDonald, J. K., S. L. Petrovic, S. M. McCann, and J. G. Parnavelas (1982) The development of beta-adrenergic receptors in the visual cortex of the rat. Neuroscience $7: 2649-2655$.

Menkes, D. B., J. M. Baraban, and G. K. Aghajanian (1981) Prazosin selectively antagonizes neuronal responses mediated by alpha $a_{1}$ adrenoceptors in brain. Naunyn Schmiedebergs Arch. Pharmacol. 317. 273-275

Mesulam, M. M., A. D. Rosen, and E. J. Mufson (1984) Regional variations in cortical cholinergic innervation: Chemoarchitectonics of acetylcholinesterase-containing fibers in macaque brain. Brain Res. 311: 133-141.

Minneman, K. P., A. Hedberg, and P. M. Molinoff (1979) Comparison of beta-adrenergic subtypes in mammalian tissue. J. Pharmacol. Exp. Ther. 211: 502-508.

Mitzdorf, U., and W. Singer (1979) Excitatory synaptic ensemble properties in the visual cortex of the macaque monkey: A current source density analysis of electrically evoked potentials. J. Comp. Neurol. 187: 71-84.

Morrison, J. H., and S. L. Foote (1986) Noradrenergic and serotoninergic innervation of cortical, thalamic, and tectal visual structures in old and new world monkcys. J. Comp. Ncurol. 243: 117-138.

Morrison, J. H., S. L. Foote, M. E. Mulliver, F. E. Bloom, and H. G. W. Lidov (1982) Noradrenergic and serotonergic fibers innervate complementary layers in monkey primary visual cortex: An immunocytochemical study. Proc. Natl. Acad. Sci. USA 79: 2401-2405.

Needler, M. C., C. Shaw, and M. Cynader (1984) Characteristics and distribution of muscimol binding sites in cat visual cortex. Brain Res. 308: 347-353.

O'Kusky, J., and M. Colonnier (1982) A laminar analysis of the number of neurons, glia and synapses in the visual cortex (area 17) of adult macaque monkeys. J. Comp. Neurol. 210: 278-290.

Olsen, R. W., F. W. Snowhill, and J. K. Wamsley (1984) Autoradiographic localization of low affinity GABA receptors with ${ }^{3} \mathrm{H}$-bicuculline methochloride. Eur. J. Pharmacol. 99: 245-247.

Palacios, J. M., and M. J. Kuhar (1980) Beta-adrenergic-receptor localization by light microscopic autoradiography. Science $208: 1378$ 1380 .

Palacios, J. M., D. L. Niehoff, and M. J. Kuhar (1981a) ${ }^{3}$ H-Spiperone binding sites in brain: Autoradiographic localization of multiple receptors. Brain Res. 213: 277-289.

Palacios, J. M., D. L. Niehoff, and M. J. Kuhar (1981b) Receptor autoradiography with tritium-sensitive film: Potential for computerized densitometry. Neurosci. Lett. 25:101-105. 
Palacios, J. M., A. Probst, and R. Cortés (1986) Mapping in the human brain. Trends Neurosci. 9: 284-289.

Parnavelas, J., and J. K. McDonald (1983) The cerebral cortex. In Chemical Neuroanatomy, P. C. Emson, ed., pp. 505-549, Raven, New York.

Pazos, A., and J. M. Palacios (1985) Quantitative autoradiographic mapping of serotonin receptors in the rat brain. I. Serotonin-I receptors. Brain Res. 346: 205-230.

Pazos, A., R. Cortés, and J. M. Palacios (1985) Quantitative autoradiographic mapping of serotonin receptors in the rat brain. II. Serotonin-2 receptors. Brain Res. 346: 231-249.

Penney, J. B., Jr., H. S. Pan, A. B. Young, K. A. Frey, and G. W. Dauth (1981) Quantitative autoradiography of muscimol receptors. Science 214: 1036-1038.

Peroutka, S. J., and S. H. Snyder (1979) Multiple serotonin receptors: Differential binding of ${ }^{3} \mathrm{H}-5$-hydroxy-tryptamine, ${ }^{3} \mathrm{H}$-lysergic acid diethylamide and ${ }^{3} \mathrm{H}$-spiroperidol. Mol. Pharmacol. 16: 687-699.

Pcroutka, S. J., and S. H. Snyder (1981) Two distinct serotonin receptors: Regional variations in receptor binding in mammalian brain. Brain Res. 208: 339-347.

Peters, A., and E. G. Jones (1984) Cerebral Cortex, Vol. 1: Cerebral Components of the Cerebral Cortex, Plenum, New York.

Peters, A., and E. G. Jones (1985) Cerebral Cortex. Vol. 3, Plenum, New York.

Quirion, R., R. P. Hammer, Jr., M. Herkenham, and C. B. Pert (1981) Phencyclidine (angel dust) O "opiate" receptors: Visualization by tritium-sensitive film. Proc. Natl. Acad. Sci. USA 78: 5881-5885.

Rainbow, T. C., and A. Biegon (1983) Quantitative autoradiography of ${ }^{3} \mathrm{H}$-prazosin binding sites in rat forebrain. Neurosci. Lett. 40: 221226.

Rainbow, T. C., W. V. Bleisch, and B. S. McEwen (1982) Quantitative densitometry of neurotransmitter receptors. J. Neurosci. Methods 198: 239-243.

Rainbow, T. C., A. Biegon, and D. J. Berck (1984a) Quantitative receptor autoradiography with tritium-labeled ligands: Comparison of biochemical and densitometric measurements. J. Neurosci. Methods 11:231-241.

Rainbow, T. C., B. Parsons, and B. B. Wolfe (1984b) Quantitative autoradiography of $\alpha_{1}$ - and $\alpha_{2}$-adrenergic receptors in rat brain. Proc. Natl. Acad. Sci. USA 81: 1585-1589.

Rakic, P., and P. S. Goldman-Rakic (1982) Development and modifiability of the cerebral cortex. Neurosci. Res. Prog. Bull. 20: 429611

Rockland, K. S., and J. S. Lund (1983) Intrinsic laminar lattice connections in primate visual cortex. J. Comp. Neurol. 216: 303-318.

Rockland, K. S., and D. N. Pandya (1981) Cortical conncctions of the occipital lobe in the rhesus monkey: Interconnections between areas $17,18,19$ and the superior temporal sulcus. Brain Res. 212: 249270.

Rogawski, M. A., and G. K. Aghajanian (1980) Activation of lateral geniculate neurons by norepinephrine: Mediation by an alpha-adrenergic receptor. Brain Res. 182: 345-359.

Shaw, C., and M. Cynader (1986) Laminar distribution of receptors in monkey (Macaca fascicularis) geniculostriate system. J. Comp. Neurol. 248: 301-312.
Shaw, C., M. C. Needler, and M. Cynader (1984) Ontogenesis of muscimol binding sites in cat visual cortex. Brain Res. 13: 331-334.

Smith, D. A., J. F. Bates, and D. W. Gallager (1984) Sensitivities to norepinephrine and serotonin developing dorsal raphe neurons. Neurosci. Abstr. 10: 1037.

Somogyi, P., A. Cowey, N. Halasz, and T. F. Freund (1981) Vertical organization of neurones accumulating $\left[{ }^{3} \mathrm{H}\right]-\mathrm{GABA}$ in visual cortex of rhesus monkey. Nature 294: 761-763.

Tallman, J. F., and D. W. Gallager (1985) The GABA-ergic system: A locus of benzodiazepine action. Annu. Rev. Neurosci. 8: 21-44.

Unnerstall, J. R., T. A. Kopajtic, and M. J. Kuhar (1984a) Distribution of $\alpha$-2-agonist binding sites in the rat and human central nervous system: Analysis of some functional anatomical correlates of the pharmacologic effects of clonidine regulated adrenergic agents. Brain Res. Rev. 7:69-101

Unnerstall, J. R., R. D. Marshall, E. B. De Souza, and M. J. Kuhar (1984b) Receptor autoradiography in brain: Coping with regional differences in autoradiographic efficiency with tritium. Fed. Proc. 43. 228.

Van Essen, D. C. (1986) Functional organization of primate visual cortex. In Cerebral Cortex, A. Peters and E. J. Jones, eds., pp. 259329, Plenum, New York

Wamsley, J. K. (1985) Autoradiographic localization of receptor sites in the cerebral cortex. In Cerebral Cortex, Vol. 2, E. G. Jones and A Peters, eds., pp. 173-202, Plenum, New York.

Wamsley, J. K., and J. M. Palacios (1984) Apposition techniques of autoradiography for microscopic receptor localization. In Current Methods in Cellular Neurobiology, Vol. 1: Anatomical Techniques, J. L. Barker and J. F. McKelvy, eds., pp. 241-267, Wiley, New York.

Wamsley, J. K., M. A. Zarbin, N. J. M. Birdsall, and M. J. Kuhar (1980) Muscarinic cholinergic receptors: Autoradiographic localization of high and low affinity agonist binding sites. Brain Res. 200:112.

Wamsley, J. K., J. M. Palacios, W. S. Young, III, and M. J. Kuhar (1981) Autoradiographic determination of neurotransmitter receptor distributions in the cerebral and cerebellar cortices. J. Histochem. Cytochem. 29: 125-135.

Wise, S. P., and M. Herkenham (1982) Opiate receptor distribution in the cerebral cortex of the rhesus monkey. Science 218: 387-389.

Young, W. S., III, and M. J. Kuhar (1979) A new method for receptor autoradiography: $\left[{ }^{3} \mathrm{H}\right]$-opoid receptors in rat brain. Brain Res. 179 255-270.

Young, W. S., III, and M. J. Kuhar (1980a) Noradrenergic alpha-1 and alpha-2 receptors: Light microscopic autoradiographic localization. Proc. Natl. Acad. Sci. USA 77: 1696-1700.

Young, W. S., III, and Kuhar, M. J. (1980b) Anatomical mapping of clonidine $(\alpha-2$ noradrenergic) receptors in rat brain: Relation to function. In Psychopharmacology of Clonidine, H. Lal and S. Fielding, eds., pp. 41-52, Liss, New York.

Young, W. S., III, and Kuhar, M. J. (1980c) Radiohistochemical localization of benzodiazepine receptors in rat brain. J. Pharmacol. Exp. Ther. 212: 337-346. 